\title{
Formação docente e diversidade de gênero no ensino superior: uma análise das
}

\section{matrizes curriculares}

\author{
Teacher education and gender diversity in higher education: an analysis of curricular matrices \\ Formación docente y diversidad de género en la educación superior: un análisis de matrices \\ curriculares
}

Recebido: 27/08/2021 | Revisado: 04/09/2021 | Aceito: 13/09/2021 | Publicado: 14/09/2021

Genésia Ferreira dos Santos

ORCID: https://orcid.org/0000-0002-2241-3688 Instituto Federal de Educação, Ciência e Tecnologia Goiano, Brasil E-mail: gene.sia@hotmail.com

Jesiel Souza Silva

ORCID: https://orcid.org/00-0002-6682-3750 Instituto Federal de Educação, Ciência e Tecnologia Goiano, Brasil E-mail: jesiel.souza@ifgoiano.edu.br

\begin{abstract}
Resumo
O presente artigo tem a intenção de desmistificar algumas classificações que envolvam a diversidade de gênero no âmbito educacional superior. Para isso, foram analisadas as matrizes curriculares dos cursos de licenciatura em Pedagogia, Matemática, Biologia, História, Geografia, Educação Física, Física, Letras e Química da Universidade Federal de Jataí-Goiás. Procurou-se identificar se os referidos cursos têm incluído em suas disciplinas temas que provoquem a reflexão sobre diversidade de gênero. Com isso, o intuito desta pesquisa é o de revelar como a diversidade de gênero tem sido pautada nos cursos universitários apontados acima; ainda, se estão abrangendo os esclarecimentos de conceitos existentes nas classes LGBTTTs, que são: Lésbicas, Gays, Bissexuais, Travestis, Transexuais e Transgêneros. Para tanto, nos baseamos nas discussões de Tomaz Tadeu da Silva (1999), Jimena Furlani (2011) e Guacira Lopes Louro (2010), autores de referência na temática da diversidade. Esta pesquisa se classifica como bibliográfica e documental, de cunho qualitativo, com coleta de dados secundários através das ementas das disciplinas e projetos pedagógicos dos cursos. A intenção é fomentar uma visão menos homo/bi/transfóbica, que intensifique a problematização do tema no Ensino Superior. Por meio deste estudo conceitual, é possível que os estudantes abordem o assunto de forma multidisciplinar e tratem da diversidade, tornando-se, assim, indivíduos que compreendam o mundo em suas múltiplas diversidades culturais.
\end{abstract}

Palavras-chave: Diversidade; Gênero; Ensino superior.

\begin{abstract}
This article intends to demystify some classifications that involve gender diversity in higher education. For this, the curricular matrices of the degree courses in Pedagogy, Mathematics, Biology, History, Geography, Physical Education, Physics, Literature and Chemistry at the Federal University of Jataí-Goiás were analyzed. We tried to identify whether these courses have included themes in their disciplines that provoke reflection on gender diversity. Thus, the purpose of this research is to reveal how gender diversity has been guided in the university courses mentioned above; still, the clarification of concepts existing in the LGBTTT classes is being covered, which are: Lesbians, Gays, Bisexuals, Transvestites, Transsexuals and Transgender. To do so, we base ourselves on the discussions of Tomaz Tadeu da Silva (1999), Jimena Furlani (2011) and Guacira Lopes Louro (2010), reference authors on the theme of diversity. This research is classified as bibliographic and documental, qualitative in nature, with secondary data collection through the syllabuses of the disciplines and pedagogical projects of the courses. The intention is to promote a less homo/bi/transphobic view, which intensify the problematization of the theme in Higher Education. Through this conceptual study, it is possible for students to approach the subject in a multidisciplinary way and deal with diversity, thus becoming individuals who understand the world in its multiple cultural diversities.
\end{abstract}

Keywords: Diversity; Genre; University education.

\section{Resumen}

Este artículo pretende desmitificar algunas clasificaciones que involucran la diversidad de género en la educación superior. Para ello, se analizaron las matrices curriculares de las carreras de Pedagogía, Matemáticas, Biología, Historia, Geografía, Educación Física, Física, Idiomas y Química de la Universidad Federal de Jataí-Goiás. Se intentó identificar si estos cursos han incluido temas que provoquen la reflexión sobre la diversidad de género en sus disciplinas. Así, el propósito de esta investigación es revelar cómo se ha orientado la diversidad de género en los 
cursos universitarios antes mencionados; Aún así, se está cubriendo la aclaración de conceptos existentes en las clases LGBTTT, que son: Lesbianas, Gays, Bisexuales, Travestis, Transexuales y Transgénero. Para ello, nos basamos en las discusiones de Tomaz Tadeu da Silva (1999), Jimena Furlani (2011) y Guacira Lopes Louro (2010), autores de referencia sobre el tema de la diversidad. Esta investigación se clasifica en bibliográfica y documental, de carácter cualitativo, con recolección de datos secundarios a través de los temarios de las disciplinas y proyectos pedagógicos de los cursos. La intención es promover una mirada menos homo / bi / transfóbica, que intensifique la problematización del tema en la Educación Superior. A través de este estudio conceptual, es posible que los estudiantes aborden el tema de manera multidisciplinar y aborden la diversidad, convirtiéndose así en individuos que comprenden el mundo en sus múltiples diversidades culturales.

Palabras clave: Diversidad; Género; Enseñanza superior.

\section{Introdução}

Há uma formação cultural erudita que afirma as colocações e posições em que o indivíduo deva permanecer. Nas questões de gênero, os sujeitos são afirmados em maior ênfase pela cultura das cores rosa ou azul, a começar na revelação do sexo do bebê - em que se referem a essas cores - e na construção de seus enxovais, em que essa dicotomia prevalece reforçada. Dessa forma, os indivíduos estão indiretamente universalizados, independentemente de sua identidade de gênero. Isso ocorre, pois, o universo ditará seu perfil pertencente a determinada classificação identitária sem se importar em manifestações futuras que esse indivíduo venha estabelecer. Esse indivíduo estará fora do padrão ditado pela sociedade, que estimulará sua identidade em posições determinantes, sem consciência nenhuma do estrago que isso lhe causará. Se pensarmos nos educandos que estão chegando na educação infantil, fica evidente que eles adentram a escola já customizados em seus seios familiares à condição dicotômica menino ou menina.

Para desmistificar esses desarranjos de ações que correlacionam os comportamentos, precisam ser trivializados e estudados os referentes temas: homossexualidade, heterossexualidade, homofobia, heteronormatividade, transgeneridade, travestilidade, bissexualidade, lesbianidade, transexualidade, identidade de gênero e papel de gênero. O esclarecimento dos referidos termos trará subsídios para contextualizar fases da nossa construção social, entendendo, assim, o próprio indivíduo como ser social, mesmo com suas diferenças e estilos, gostos e culturas diferenciadas, buscando sempre o reconhecimento do respeito e a compreensão para a diversidade social.

É importante que haja estudos em áreas afins das licenciaturas, considerando que o tema se torna importantíssimo nesses cursos, pois eles terão como foco a condução para a formação de futuros profissionais que irão vivenciar em sala de aula essa problemática social da diversidade e suas culturas. Por conta disso, é necessário que abordem essa temática fazendo colocações e posicionamentos que venham elucidar de maneira amena os ditos e postulados do senso comum, os quais muitas vezes servem de ferramentas para ataques homo/bi/transfóbicos.

Se os educandos não tiverem acesso a disciplinas que venham teorizar o tema nas magistraturas, o que acontecerá é que, de forma indireta, não pautando o assunto e não respeitando as diversidades e suas identidades, seremos responsáveis pelas ações opressivas e cruéis de discriminação que englobam as socializações educacionais e que são enraizadas desde o início das escolarizações. O processo dessa construção social nos remete a ambientes onde os indivíduos já estão hostis e moldados pela cultura que foram acometidos. Essa construção - ou mesmo desconstrução - causa muito sofrimento, especialmente naqueles que transcendem as barreiras em que sua identidade de gênero não comporta esse meio social.

Segundo Furlani (2011), "para muitas pessoas, gênero, raça, etnia, condição física, orientação sexual, nacionalidade, etc. são marcas identitárias responsáveis por experiências de exclusão tão significativas quanto a classe social” (p.23). A educação, ao longo de sua trajetória, aparenta demonstrar essa exclusão, representada de forma dissimulada pelos educadores e suas atitudes em sala e em encontros coletivos, como conselhos de classes. Fica evidente que existem lacunas nas matrizes curriculares, além de distanciamentos entre o espaço teórico e a prática referente à temática; ademais, há falta de respeito que aparece de forma eventual e naturalizada, pois fomos criadas dentro de visões preconceituosas. Furlani (2011) afirma que a 
posição e produção e reprodução da exclusão, que cada vez mais compromete politicamente a Escola com as mudanças socais, tem possibilitado, nos tempos recentes, discussões sobre o papel na aproximação e convergência entre os "direitos humanos", a "cidadania plena" e a "inclusão social" A suposta neutralidade política escolar é definitivamente posta em xeque. (p.23).

$\mathrm{O}$ assunto desconcerta a atitude de professores que procuram imediatamente fugir da questão da diversidade de gênero no âmbito educacional. É necessário desmistificar os comportamentos equivocados dos educadores e das gestões pedagógicas, pois agem de acordo com o determinismo e a heteronormatização dos indivíduos e seus comportamentos desde a educação infantil.

Para a Educação Sexual, essa lógica (que no exemplo das identidades nacionais "legitima" a xenofobia) serve para o entendimento da homofobia. Sobretudo, quando, diante da representação "monstruosa" da identidade homossexual (ou de outra identidade sexual subordinada), algumas pessoas ou instituições assumem o papel de paladinos da justiça moral, como se estivessem fazendo um "favor social", "limpando" as ruas através de atos de violência verbal e/ou física dos monstros, dos maus elementos, dos depravados, daqueles que depõem contra a família e os bons costumes. Nesse caso, a representação monstruosa naturaliza a violência e a subjugação de um tipo de sujeito representado como diferente, como monstruoso, por outro tipo (o "normal") que é "autorizado" socialmente a cometer os atos de discriminação e preconceito. (Furnali, 2007, p.278)

Dessa forma, seria um território de sensibilidade trazer a temática da diversidade de gênero no ambiente educacional? Para o educador, nos momentos de abordagem - ou mesmo nos conflitos que envolvam esse assunto -, estariam eles preparados para aprofundar com veemência essa problemática? Teriam eles, abertura em seus currículos que permitisse essa contextualização?

É preciso expandir aos planejamentos de políticas educacionais o tema de forma conceitual como meio de assegurar melhores condições de direito cidadão para a classificação LGBTTTs (Lésbicas, Gays, Bissexuais, Travestis, Transexuais e Transgêneros). Também é preciso a abordagem do assunto em ambiente familiar, por conta da não aceitação das identidades de gênero que transcendem os corpos fisiológicos, pois os indivíduos sofrem desde a infância.

Destaca-se que, geralmente, ocorre a fragmentação do tema em relação a sua contextualização, mas a problemática vai além dos muros das escolas, gerando problemas sociais gravíssimos que intensificam de forma cruel as gerações no âmbito educacional. A compreensão de embasamento referencial das referidas problematizações nos projetos pedagógicos de cursos (PPCs) farão a diferença, pois se espera que, com explicações dessas pautas, amenizem-se muitas questões que envolvem o assunto.

Tendo isso em vista, a finalidade deste artigo é analisar as bases curriculares dos cursos do Ensino Superior da Universidade Federal de Jataí, observando se eles delimitam em suas matrizes curriculares assuntos e temas que persistem na socialização de indivíduos que transcendem a heteronormatização. Trata-se de uma temática bastante necessária, pois abrange a condição do educando prestes a exercer sua profissão, que é formar psico e socialmente indivíduos diversos.

Para citar alguns exemplos, aos cursos de Pedagogia e Educação Física, é essencial a abordagem dessa temática, pois abrangem o processo educacional desde a primeira infância - anos iniciais - e nessa etapa se faz urgente a conscientização e desconstrução de conceitos impostos ou construídos como forma de composição humana exata e intacta. Nessa fase, observamos ser o momento mais perturbador e fragmentado de achismos e falta de respeito com os indivíduos que transcendem a vertente do estabelecido como "normal". Então, caberá ao profissional pedagogo, se assim for assessorado em seus estudos de maneira conceitual, instruir um assunto tão caro à formação da criança.

Já os cursos de Geografia, Matemática, História e Letras, disciplinas que o profissional vai atuar de forma direta com os educandos no Ensino Fundamental II, estão localizados em uma etapa de bastante curiosidade e descobrimento individuais. 
Essa fase é o momento em que se faz urgente a desconstrução de conceitos que não foram interiorizados ainda, a fim de tornar os pré-adolescentes mais seguros de suas identidades.

Por último - e não menos importante -, os cursos de Ciências Biológicas, Física e Química, que abrangem temas voltados a um grupo mais específico de indivíduos, tendem a ser mais cruéis no Ensino Médio com os indivíduos que transcendem a condição normativa. Os que, por algum milagre, chegaram ao Ensino Médio sendo vítimas dessa condição, estão cheios de cicatrizes feitas ao longo do percurso de ensino.

O objetivo específico deste artigo é buscar teorias fundamentadas em estudos que estejam voltados à educação de gênero, verificando se colaboram de maneira direta e indireta, auxiliando educadores e educandos para uma socialização em aceitação da diversidade de gênero. Para tanto, verificaremos se os corpos docente e discente têm acesso, em suas matrizes curriculares, a aportes teóricos que os ampare em condições que demandem soluções em situações de conflito.

Organizamos as seções deste trabalho da seguinte maneira: A seção Diversidade de gênero abrange conceitos teóricos sobre a diversidade de gênero, sobretudo no contexto educacional, e explicita o quão problemático aos sujeitos é enfrentar a homofobia. A seção Metodologia da Pesquisa descreve as etapas para execução desta investigação. Por sua vez, a seção Diversidade de Gênero e Ensino Superior traz os resultados da análise das matrizes curriculares de licenciaturas da Universidade de Jataí-GO. Finalmente, abordamos algumas reflexões alcançadas a partir da pesquisa.

\section{Metodologia}

Os procedimentos metodológicos para execução dessa pesquisa se dividem em duas etapas. A primeira, de levantamento bibliográfico, foi configurada pela seleção de artigos científicos e demais obras acadêmicas. A segunda, de caráter documental, contou com o levantamento das matrizes curriculares dos cursos de licenciatura nas graduações de Pedagogia, Matemática, Biologia, História e Geografia, Educação Física, Física, Letras e Química da Universidade Federal de Jataí (UFJ). Embora a instituição conte com outros cursos, optamos por verificar esses, a fim de observar se suas ementas oferecem disciplinas que abordam o tema diversidade de gênero no âmbito educacional. Esse levantamento foi realizado a partir das matrizes curriculares e dos PPCs das referidas formações, disponibilizados nos sites dos cursos.

Para fazer o levantamento das matrizes curriculares, usamos como processo didático a busca por palavras-chave que contemplam o assunto, como: "Diversidade", "Sexualidade", "Teoria Queer”, "Identidade de gênero", "Discriminação", "Gênero" e "Diferença".

A Universidade Federal de Jataí - UFJ foi fruto de um projeto de interiorização da própria Universidade Federal de Goiás - UFG. Em junho de 1979, as comissões do Lions Club se pronunciaram em forma de abaixo assinado requerendo a instauração da UFJ, na época, conhecida como Regional Jataí. Como resultado, em março de 1980, foi então instituído o Campus Avançado de Jataí, firmando parceria com a Prefeitura Municipal de Jataí. O prédio foi oficializado em 19 de março de 1980 e seu primeiro vestibular foi aplicado no ano seguinte, com vagas para os cursos de Química, Física e Matemática.

Atualmente, reconhecida como Universidade Federal de Jataí-UFJ, conta com 24 cursos, distribuídos em dois campi: o Riachuelo, situado no centro da cidade, oferecendo os cursos de Pedagogia, Geografia e alguns ambientes administrativos; e o Jatobá-Cidade Universitária José Cruciano de Araújo, com os cursos de graduação em Agronomia, Biomedicina (bacharelado), Ciências Biológicas (bacharelado), Ciências Biológicas (licenciatura), Ciências da Computação (bacharelado), Direito (bacharelado), Educação Física (bacharelado), Educação Física (licenciatura), Enfermagem, Engenharia Florestal, Física (licenciatura), Fisioterapia, Geografia (bacharelado), Geografia (licenciatura), História (licenciatura), Letras (licenciatura em Inglês), Letras (licenciatura em Português), Matemática (licenciatura), Medicina, Medicina Veterinária (bacharelado), Pedagogia (licenciatura noturno), Pedagogia (licenciatura matutino), Psicologia, Química (bacharelado), Química (licenciatura) e Zootecnia. 
Há também outros cursos de graduação e cursos de pós-graduação, com destaque para a Programa de Pós-Graduação strictu sensu em nível de doutorado em Geografia e os seguintes cursos de mestrado: Agronomia, Geografia, Educação, Ciências da Saúde, e os mestrados profissionais em Matemática e Letras. Os Cursos de Especialização também são organizados de acordo com a demanda. A instituição tem a circulação de cerca de quatro mil alunos em Jataí. Ela é desmembrada da Universidade Federal de Goiás-UFG, que teve a sua primeira sede fundada na cidade de Goiânia no ano de 1960 por meio de decreto do então presidente Juscelino Kubitscheck. Sua história, portanto, é relacionada com a expansão do ensino superior para o interior do Brasil.

\section{Diversidade de Gênero no Contexto Educacional}

Falar da diversidade no âmbito educacional sempre foi um tema de difícil acesso, pois o assunto requer entendimento, uma vez que é polêmico e subjugado o tempo todo. Diversos parâmetros normativos nacionais afirmam o compromisso da escola com a promoção da justiça e igualdade, dentre eles a Lei de Diretrizes e Bases da Educação Nacional e o Plano Nacional de Direitos Humanos. Apesar de todo aparato legal em questão, existe uma limitação transversal que reprime a precisão da exploração e elucidação das argumentações. A legislação não deixa de ser produtora de discriminação, uma vez que não trata as temáticas de maneira mais acessível, protegendo de forma indireta e disfarçada o indivíduo que transcende a heteronormatização. Segundo Louro (1997),

Os sentidos precisam estar afiados para que sejamos capazes de ver, ouvir, sentir as múltiplas formas de constituição dos sujeitos implicadas na concepção, na organização e no fazer cotidiano escolar. O olhar precisa esquadrinhar as paredes, percorrer os corredores e salas, deter-se nas pessoas, nos seus gestos, suas roupas; é preciso perceber os sons, as falas, as sinetas e os silêncios; é necessário sentir os cheiros especiais; as cadências se os ritmos marcando os movimentos de adultos e crianças. Atentas/os aos pequenos indícios, veremos que até mesmo o tempo e o espaço da escola não são distribuídos nem usados - portanto, não são concebidos - do mesmo modo por todas as pessoas (p.59).

Com isso, afirmamos que existem estudiosos comprometidos com a problemática dos gêneros. Há diversos artigos que trazem o tema e abrangem o contexto do impacto gerado na socialização das pessoas que fogem da heteronormatização. Há autores conceituados, como Tomaz Tadeu da Silva (1999), Jimena Furlani (2011) e Guacira Lopes Louro (2010), além de outros que marcam essa instância da luta de pertencimentos e reconhecimentos dos gêneros e suas classificações na sociedade. De qualquer maneira, a vulnerabilidade e a falta de conscientização educacional se tornam temas "diferentes" e tratados com desprezo. Os assuntos necessitam ser pautados nas matrizes curriculares, tornando o trabalho dos educadores mais consistente e os temas dignos e seguros.

Há dificuldades encontradas até mesmo nas políticas educacionais, por isso, precisamos de apoio em prol de um currículo que venha abranger, de fato, a questão da diversidade de gênero no sistema de Ensino Superior e, posteriormente, em suas ramificações (Ensino Médio, Ensino Fundamental I e II e Educação Infantil). Falar de gênero e suas nomenclaturas sempre envolverá as relações sociais e suas construções culturais. Para Louro (2014),

Diferenças, distinções, desigualdades... A escola entende disso. Na verdade, a escola produz isso. Desde seus inícios, a instituição escolar exerceu uma ação distintiva. Ela se incumbiu de separar os sujeitos - tornando aqueles que nela entravam distintos dos outros, os que a ela não tinham acesso. Ela dividiu também, internamente, os que lá estavam, através de múltiplos mecanismos de classificação, ordenamento e hierarquização. A escola que nos foi legada pela sociedade ocidental moderna começou por separar adultos de crianças, católicos e protestantes. Ela também se fez diferente para os ricos e para os pobres e ela imediatamente separou os meninos das meninas (p.61).

Segundo a referida autora, a escola propagou e continua exercendo sua arbitrariedade diante da sociedade, uma vez 
que é causadora de repartições presentes em nossa realidade. Desde o princípio, a instituição recebeu alguns que não exerciam os mesmos direitos e, aos poucos, passaram a ter acesso à educação; desde então, as transformações foram acontecendo - ainda que, implicitamente, executasse a diferença entre seus indivíduos -, sendo preciso haver modificações nas estruturas, no trabalho docente e nas avaliações.

Sobre o assunto de diversidade sexual ou das multiplicidades sexuais, adentramos em um território de lutas, de conflitos e de tensões, pois quem rompe as convenções estabelecidas culturalmente e primordialmente pelos preceitos religiosos se submete constantemente ao enfrentamento de uma realidade desafiadora. A índice de elucidação, a diversidade sexual traz várias categorias que se destacam, como a homossexualidade, a lesbianidade, a bissexualidade, a travestilidade, a transexualidade e a transgeneridade. Para Pamplona (2012),

Ao observar tais proposições, vê-se que essas transitam por algumas áreas de saber, como psicologia, psiquiatria, genética, mas todas se referem ou emergem de um saber biológico, naturalizante e essencialista. Este constrói uma explicação casual para a homossexualidade, bissexualidade, lesbianidade, transvestilidade, transexualidade, saber que transita entre, produzi-la como afronta a uma naturalidade dicotômica - lida por macho/fêmea, homem/mulher - ou por uma explicação biologicista que atribui uma ordem da nascença para as homossexualidades, que afirma: ele/ela nasce assim, não há mais o que ser feito para inverter essa realidade posta corporalmente, biologicamente (p.120).

Portanto, fica evidente o quanto as transições dessas classificações foram impostas e impregnadas como determinantes dos indivíduos que transcendem a heteronormatização a qual a sociedade se insere. Em relação a diversidade, Aranha (2011) assegura que a diversidade sexual e de gênero existe de diferentes formas e valores nas hierarquias construídas por constituições e poder. Ademais, que sempre foram delimitadas por ações violentas e exclusões de determinados grupos e indivíduos. Outrossim, afirma que se trata de:

compreender culturas diferentes, de diferentes agrupamentos sociais. Diversidade relaciona-se com a diferença, mas nada tem a ver com classificações quanto à inferioridade ou superioridade de um grupo sobre o outro. Em outras palavras, respeitar a diversidade não significa ser tolerante com valores, costumes, hábitos que julgamos inferiores aos nossos (Aranha, 2011, p. 55).

Desta forma, fica evidente o quanto necessitamos interagir nesse contexto com urgência em estudos que aprofundam o tema aqui explorado. Acreditamos que, se unirmos escolas, professores e comunidades escolares, trabalharemos em uma mesma linha de desconstrução da moralidade heteronormativa. Face ao exposto, compreendemos a existência de uma fragilidade por parte dos profissionais da educação, pela ausência de uma formação acadêmica que os prepare para a compreensão científica desse eixo. Isso reflete o fato de sermos pertencentes a uma cultura que possui inúmeros dogmas, crenças e uma construção social hegemônica da heteronormatividade, que subalterniza e inferioriza as orientações sexuais fora do padrão.

Diante dessas entrevistas, Balieiro e Risk (2014) se questionam:

Mas como lidar com evidências de que a escola é espaço de expressão de violências, preconceitos e discriminações se a concebemos como espaço fomentador da cidadania? Os livros escolares não tratam dos direitos e deveres imprescindíveis para uma sociedade democrática em que a discriminação é inaceitável? Diante desses questionamentos, alguém poderia ainda afirmar que a escola nada tem a ver com situações que envolvem discriminações baseadas em gênero e sexualidade, visto que ela se apresenta como instituição "neutra" no que tange a essas diferenças. Segundo essa perspectiva, a sexualidade não é um tópico que deve ser levado em conta pela educação escolar. Portanto, não seria um equívoco responsabilizá-la pelas situações descritas? (p.151).

Continuamos questionando como podemos promover a igualdade e o reconhecimento dos pertencentes à condição da diversidade sexual? Se o espaço escolar deve ser voltado e constituinte para uma cidadania justa e igualitária, a compreensão 
não se torna visivelmente urgente? Portanto, essa percepção quase sempre se passa por despercebida e não podemos nos omitir, sendo que educadores possuem o dever de contribuir e defender os direitos dos LGBTTTs.

Necessitamos que as práticas educacionais sejam pensadas e repensadas de acordo com as necessidades de cada indivíduo e com a realidade social, estabelecendo-se dentro de seus planos e programas de trabalhos uma atitude docente condizente com a realidade social. O que cabe a nós, professores, pais, famílias e sociedade em geral, é ter atitudes esclarecedoras que conduzam as situações, rompendo com a tradicional dicotomia que associa os indivíduos a uma determinada condição biológica. Louro (1997) enfatiza que, nas "relações sociais atravessadas por diferentes discursos, símbolos, representações e práticas, os sujeitos vão se construindo como masculinos ou femininos, arranjando e desarranjando seus lugares sociais, suas disposições, suas formas de ser e estar no mundo" (p. 28).

As várias formas de discriminação em relação à vivência dos gêneros feminino e masculino ficam evidentes perante situações transcorridas nos espaços da sala de aula da educação infantil. Por exemplo, quando um menino demonstra gostar da cor rosa, de filmes de princesas, de fadas, de adereços que têm encantamento para ele, de brincar com bonecas, há imediatamente - quando não há conhecimentos adequados sobre a temática aqui apresentada - uma preocupação em que esse menino seja homossexual. No entanto, esse fator não deve ser tido como verdade, pois preferências por brinquedos, cores, músicas ou roupas do gênero oposto ao do sexo atribuído ao nascimento não definem orientação sexual. Em outras palavras, um menino que brinca de boneca não será gay em decorrência das brincadeiras atribuídas ao universo feminino.

Em relação às meninas que gostam de brincar com carrinhos, de jogar futebol ou de brincadeiras agressivas, não significa que serão lésbicas. Pensar dessa forma é insistir em uma realidade de preconceito, é pensar de maneira naturalizante, essencialista, a qual compreende os gêneros de forma dicotômica, ou seja, de um lado coisas de menino, de outro, coisas de menina. Nessa lógica, qualquer embaralhamento significa risco de uma orientação sexual desviante da norma heterossexual.

Assim, por falta de conhecimentos, muitos educadores buscam evitar que meninos e meninas misturem a vivência desses papéis de gênero, buscando preconceituosamente afastar o perigoso fantasma ou monstro das sexualidades desviantes. Como exemplo, citamos a questão das cores e dos brinquedos - o rosa é de menina e o azul do menino; meninos não podem brincar com "brinquedos de meninas e vice-versa" -, usando esse modelo heteronormativo como indicador do que é pertencente ao masculino e ao feminino.

Nesse sentido, conforme Moreno (1999),

Mesmo que tenhamos escolas mistas e que meninas e meninos se sentem ao redor das mesmas mesas, na hora do recreio os meninos jogam com os meninos e as meninas com as meninas. Nas brincadeiras livres é que exercitam espontaneamente os modelos aprendidos de conduta, é aí que aparece a fantasia com o qual cada indivíduo se identifica. Mas, curiosamente, é nesses momentos de "liberdade" que cada indivíduo se identifica. Mas, curiosamente, é nesses momentos de "liberdade" que cada indivíduo se encontra mais intensamente limitados pelas normas estabelecidas, como se tivesse "plena liberdade" para identificar-se com os arquétipos que estão destinados a ele em função de seu sexo, mas não para transgredi-los (p.30-32).

Essas pequenas situações levam pais, mães e os próprios professores a se preocuparem com o gosto e com a preferência de seus filhos e alunos, sem obterem o entendimento de que nada desse comportamento interferirá na orientação sexual da criança. O que nos inquieta é o fato de a criança, na maioria das vezes, não ter um apoio, uma segurança, ou até mesmo um esclarecimento para transitar entre os gêneros sem que com isso seja rotulada em sua identidade de gênero ou em sua orientação sexual. No decorrer de seu caminhar e descoberta, a criança que sofre discriminações poderá se perguntar o porquê de ser assim ou o porquê de não gostar de determinada coisa das quais deveria gostar por ser pertencente a um determinado sexo biológico atribuído em seu nascimento. Essa realidade e acontecimentos podem ser estimulantes de estigmas, violências, evasão escolar e, em casos mais extremos, suicídio.

De acordo com Louro (1997, p.28), “essas construções e esses arranjos são sempre transitórios, transformando-se não 
apenas ao longo do tempo, historicamente, como também se transformando na articulação com as histórias pessoais, as identidades sexuais, étnicas, de raça, de classe". Desse modo, devemos pensar em novas ações para que possamos atuar ativamente em defesa dos indivíduos considerados e classificados como minorias sexuais. Referimo-nos a minorias não no sentido se serem um pequeno grupo, mas na direção de terem sua representatividade política e social comprometida diante de poderes hegemônicos e tradicionalmente reconhecidos nas políticas públicas como superiores. Se fingirmos que eles não existem ou que não são problemas nossos não resolveremos nada, pois a diversidade sexual e de gênero estará presente e continuará circulando nas diferentes instituições sociais, como a escola.

Para Junqueira (2009),

Diante do anseio de construirmos uma sociedade e uma escola mais justas, solidárias, livres de preconceito e discriminação, é necessário identificar e enfrentar as dificuldades que temos tido para promover os direitos humanos e, especialmente, problematizar, desestabilizar e subverter a homofobia. São dificuldades que se tramam e se alimentam, radicadas em nossas realidades sociais, culturais, institucionais, históricas e em cada nível da experiência cotidiana. Elas, inclusive, se referem a incompreensões acerca da homofobia e de seus efeitos e produz ulteriores obstáculos para a sua compreensão como problema merecedor da atenção das políticas públicas (p. 13).

Portanto, o autor só vem afirmar o quanto estamos implicados na tarefa de combate à realidade do preconceito e discriminação endereçada a quem rompe os lugares tradicionais dos gêneros e das orientações sexuais. Ele ainda afirma que

É necessário estudo, paciência, debates, reflexões sobre o atual momento político e educacional brasileiro para que nós, professores, possamos perceber a riqueza da diversidade em sala de aula, sob todos os aspectos, e particularmente na questão da diversidade sexual. Se, por um lado, todos concordam acerca da beleza do aprendizado entre os diferentes, por outro, isso é muito difícil de ser conseguido, exigindo de nós grande esforço de trabalho e uma disposição para a aceitação e a superação de preconceitos que não é fácil de ser mantida (Junqueira, 2009, p.131).

A diversidade sexual refere-se à pluralidade, multiplicidade de costumes, vivências e, por essa razão, professores, pais e mães não deveriam querer que seus filhos ou alunos vivam conforme os valores heteronormativos. O fundamental é que se estabeleçam conversas, problematizações e análises, confrontando diferentes opiniões e mostrando a amplitude de valores, de códigos éticos e morais e das diferenças. Essas atitudes são geradoras de atrocidades históricas e violentas, portanto, necessitamos de que as diversidades venham a ser analisadas pelas políticas públicas, com ajuda de imediato respaldo para uma sociedade solidária e justa. Para Junqueira (2009),

Trata-se de investir em um processo de reconfiguração simbólica e política que, como tudo o que concerne à democratização das relações e à institucionalização de novas práticas pedagógicas, é contínuo, inacabado, sempre suscetível de ser revisto, ampliado e aperfeiçoado. E, por também estar sujeito a ameaças e a retrocessos, esse processo requer sempre maior empenho, capacidade de articulação, criatividade, responsabilidade e ousadia, em diversos espaços, níveis, direções e sentidos (Junqueira, 2009, p. 185).

Os professores devem criar situações que permitam explorar as múltiplas possibilidades de se exercer a diversidade sexual e os gêneros, sem com isso postular um discurso romântico ou de salvação de um grupo inferiorizado, pois pessoas que não vivem os gêneros dados no nascimento - a exemplo das pessoas transexuais, ou pessoas que vivem orientações sexuais distintas da heterossexual - não são pobres coitadas. Ao contrário, são pessoas em igualdade de condição humana, apenas precisando que seus direitos sociais, jurídicos e políticos sejam reconhecidos de forma equivalente às pessoas heterossexuais ou que exercem gêneros condizentes ao de seu nascimento. 


\subsection{Ser diferente se torna uma vertente problematizadora no nosso sistema}

É gritante como a sociedade não está nem um pouco acostumada com a questão da diversidade em suas socializações. Isso porque saber que a diversidade existe é até viável, mas quando nos deparamos mudança assustadora até para nosso consciente. É normal perceber que, para os próprios educadores, a situação é desconfortável, ainda que convivam e saibam da existência de identidades de gênero múltiplas em sala de aula, quando ajudam os educandos de maneira indireta a vencer barreiras complicadas. O professor, quando questionado sobre a questão, se mantém neutro, não optando em falar sobre o tema. Esse refúgio é alternativo e colabora com a persistência de brincadeiras desagradáveis e maldosas que reforçam a homofobia no âmbito educacional. Louro (2014) afirma que:

Essas múltiplas identidades não podem, no entanto, ser percebidas como se fossem "camadas" que se sobrepõem umas às outras, como se o sujeito fosse se fazendo "somando-as" ou agregando-as. Em vez disso, é preciso notar que elas se interferem mutuamente, se articulam; podem ser contraditórias; provocam, enfim, diferentes "posições". Essas distintas posições podem se mostrar conflitantes até mesmo para os próprios sujeitos, fazendo-os oscilar, deslizar entre elas - perceber-se de distintos modos (p.55)

Portanto, as diferentes subdivisões provocam mudanças e lutas, sendo também diversas para cada indivíduo - que vive instâncias subordinadas e dominadas infelizmente. Há várias histórias de opressão e sofrimento, mas sempre existirão condições que os fazem compreender as relações de poder a qual estão submetidos. A homofobia, por exemplo, é o termo usado para definir o preconceito relacionado ao desprezo e ao ódio às pessoas com orientação sexual diferente da heterossexual. Nesse grupo, podemos incluir os homossexuais, as lésbicas, bissexuais, transexuais, transgêneros e as travestis.

As pessoas necessariamente não precisam ser homossexuais para serem vítimas da homofobia, basta estarem fora dos códigos dominantes para os gêneros. Por exemplo, um homem, ainda que heterossexual, se for delicado, gentil ou preferir vestuários menos tradicionais, pode ser atacado por práticas homofóbicas. Uma mulher, ao se mostrar mais dinâmica, independente, autônoma financeiramente e preferir um vestuário considerado menos feminino, ainda que seja heterossexual, poderá ser atacada por práticas discriminatórias por ser acusada de romper os códigos estipulados tradicionalmente para a vivência de seu gênero. De acordo com Borrillo (2009),

A recente preocupação com a hostilidade para com gays e lésbicas mudou a maneira como a questão vinha sendo problematizada. De fato, em vez de se dedicar ao estudo do comportamento homossexual, a atenção se volta agora para as razões que levaram essa forma de sexualidade a ser considerada, no passado, desviante. Esse deslocamento do objeto de análise sobre a homofobia produz uma mudança tanto epistemológica quanto política. Epistemológica porque não se trata exatamente de conhecer ou compreender a origem e o funcionamento da homossexualidade, mas sim de analisar a hostilidade provocada por essa forma específica de orientação sexual. Política porque não é mais a questão homossexual, mas a homofobia que merece, a partir de agora, uma problematização particular (Borrillo, 2009, p. 16).

Verifica-se que a homofobia se torna um arsenal de desaprovação para a heteronormatividade, fazendo suas vítimas não apenas os pertencentes à classificação dos LGBTTTs, mas também incluindo aqueles que transgridem a sua identidade de gênero. A exemplo, homens e mulheres que apresentam traços que não condizem com o perfil de gênero pertencente são determinantemente classificados em uma orientação sexual que não seria hetero. A palavra homofobia foi utilizada em meados de 1971, mas somente em 1990 foi configurada nos dicionários europeus. Ela tem como dispositivo pronto a repugnância por quem que não se atenta a seguir as normas postas. É também reconhecida como forma de preconceito, como a xenofobia (fobia a pessoas imigrantes de outros países), o racismo (determinação de algumas hierarquias que diferencia etnias e raças) e o antissemitismo (repúdio aos judeus). Rios (2009) afirma que

Desde o final da II Grande Guerra, preconceito e discriminação são temas disputados e estudados por intermédio de suas manifestações mais contundentes nas sociedades ocidentais: anti-semitismo, racismo e sexismo. Somente nos 
últimos anos, o preconceito e a discriminação voltados para expressões da sexualidade passaram a merecer atenção. No esforço de compreensão dos fenômenos do preconceito e da discriminação, a cada uma das aludidas manifestações associou-se um conjunto de circunstâncias, na tentativa de explicar a gênese e a reprodução destes processos (p. 57).

A partir do nascimento, os indivíduos já são enquadrados em uma situação de gênero devido a seu sexo, feminino ou masculino. Com isso, é comum que seus pais cuidem para que tudo venha rosa, ser for menina, ou tudo azul, caso a criança seja do sexo masculino. No transcorrer de sua vida, os responsáveis cuidarão para que a criança brinque e vista aquilo que demonstre o seu gênero de nascimento (seu gênero biológico), o que pode aparentar um ar de naturalidade em atribuições que, de fato, não possuem nada de natural, pois foram ensinadas cautelosamente e incansavelmente, além de serem produzidas social e culturalmente. Essa conduta não deixa de ser uma expressão da homofobia, uma vigilância de território para evitar formas contrárias à orientação sexual desejada e aos gêneros dicotômicos. Nessa perspectiva, se postula que ou se nasce homem, ou se nasce mulher, assim, não existem meios termos ou ambiguidades. Nesse viés, não se pode trair a condição de ser feminino ou masculino ou de ser heterossexual.

Para Borrillo (2009, p.19), “a homofobia é familiar”. O autor afirma que

percebemo-la como um fenômeno banal: quantos pais se inquietam ao descobrir a homofobia de seu filho adolescente, se a homossexualidade de um filho ou filha é ainda motivo de sofrimento para a família e conduz frequentemente a consultar a um terapeuta? Invisível, cotidiana e disseminada, a homofobia participa do senso comum, embora leve igualmente, a uma alienação dos heterossexuais. É por essas razões que se considera indispensável questioná-la tanto no que se refere às atitudes e aos comportamentos quanto no que diz respeito às suas construções ideológicas (Borrillo, 2009, p.19).

Portanto, quando Borrillo (2009) compreende que a homofobia é familiar, ainda que não seja percebida, quer dizer que a prática será presente quando os pais e mães de jovens LGBTTTs procuram ajuda de especialistas, pois sofrem pela condição de suas filhas e de seus filhos. Esses pais e essas mães estão sendo praticantes da carrasca homofobia; seus filhos (as) são observados, analisados e são questionados pela própria família.

De forma geral, podemos compreender a heteronormatividade como o postulado que afirma a heterossexualidade como única expressão de sexualidade e orientação sexual tida como normal, aceitável e desejável. Qualquer outra orientação sexual é tida como desviante e anormal. A heteronormatividade limita os desejos, as condutas e as identificações de gênero; assim, apenas a heterossexualidade é admitida como normal, aceitável, ajustada ao par binário masculino/feminino. A não aceitação de outras expressões de sexualidade levada a seu mais extremo radicalismo é que transforma a heterossexualidade em heteronormatividade, como o próprio nome indica. Assim, a heterossexualidade passa de uma orientação sexual - dentro de uma diversidade - para uma norma que deve ser seguida em detrimento de qualquer outra.

Em sua obra, Louro (1999) afirma que:

Ao final do século XIX, serão homens, médicos e também filósofos, moralistas e pensadores (das grandes nações da Europa) que vão fazer as mais importantes "descobertas" e definições sobre os corpos de homens e mulheres. Será o seu olhar "autorizado" que irá estabelecer as diferenças relevantes entre sujeitos e práticas sexuais, classificando uns e outros a partir do ponto de vista da saúde, da moral e da higiene. Não é de estranhar, pois, que a linguagem e a ótica empregada em tais definições sejam marcadamente masculinas; que as mulheres sejam concebidas como portadoras de uma sexualidade ambígua, escorregadia e potencialmente perigosa; que os comportamentos das classes média e alta dos grupos brancos das sociedades urbanas ocidentais tenham se constituído na referência para estabelecer o que era ou não apropriado, saudável ou bom. Nascia a sexologia. Inventam-se tipos sexuais, decidia-se o que era normal ou patológico e esses tipos passavam a ser hierarquizados. Buscava-se tenazmente conhecer, explicar, identificar e também classificar, dividir, regrar e disciplinar a sexualidade. Tais discursos, carregados da autoridade da ciência, gozavam do estatuto de verdade e se confrontavam ou se combinavam com os discursos da igreja, da moral e da lei (p. 88). 
Ainda de acordo com a autora acima citada, após esse final de século, os estudiosos e moralistas na Europa começaram a conceituar os corpos femininos e masculinos e a fazer grandes descobertas e significações, classificando-os a partir do ponto de vista moral. Nunca fora estranha à lógica masculina de ser marcadamente reconhecida como o potencial forte, comparado ao incompatível, frágil e impotente feminino. Fizeram uso do dispositivo da heteronormatividade, colocando suas normas vigentes e acreditando ser o correto. Com o apoio das ciências em sua absoluta verdade, combinavam-na aos discursos moralistas da igreja e às leis jurídicas. Assim, suas afirmações decidiram o que era normal e o que era patológico e passaram a ser hierarquizados, dividindo e disciplinando a sexualidade em vertentes dicotômicas, como: masculino/feminino, macho/fêmea, normal/anormal, homossexual/heterossexual.

Nessa perspectiva, sexo-gênero-sexualidade são vistos como decorrências causais, ou seja, sexo biológico define o gênero, que, por sua vez, determina a orientação sexual. Essa visão, lembramos, é oposta à que compartilhamos. Buscamos, por outro lado, mostrar que essa relação determinante não é natural, biológica ou obrigatória. A heteronormatividade constantemente produz e renova a norma heterossexual; ela afirma que todas as pessoas devem ser heterossexuais, além de fabricar, produzir e reiterar uma conduta tida como superior e desejada. Nessa direção Louro (2009) sustenta em seus argumentos que

Esse alinhamento (entre sexo-gênero-sexualidade) dá sustentação ao processo de heteronormatividade, ou seja, à produção e à reiteração compulsória da norma heterossexual. Supõe-se, segundo essa lógica, que todas as pessoas sejam (ou devam ser) heterossexuais - daí que os sistemas de saúde ou de educação, o jurídico ou o midiático sejam construídos à imagem e semelhança desses sujeitos. São eles que estão plenamente qualificados para usufruir desses sistemas ou de seus serviços e para receber os benefícios do Estado. Os outros, que fogem à norma, poderão na melhor das hipóteses ser reeducados, reformados (se for adotada uma ótica de tolerância e complacência); ou serão relegados a um segundo plano (tendo de se contentar com recursos alternativos, restritivos, inferiores); quando não forem simplesmente excluídos, ignorados ou mesmo punidos. Ainda que se reconheça tudo isso, a atitude mais frequente é a desatenção ou a conformação. A heteronormatividade só vem a ser reconhecida como um processo social, ou seja, como algo que é fabricado, produzido, reiterado, e somente passa a ser problematizada a partir da ação de intelectuais ligados aos estudos de sexualidade, especialmente aos estudos gays e lésbicas e à teoria queer. (p. 90).

Diante disso, a heteronormatividade é o regimento conhecido e disseminado que ensina práticas educativas de socialização nas instituições e em família e que automaticamente nos induz a estarmos frisando sempre o que é certo ou errado a determinado gênero. A partir disso, todos os indivíduos necessitam serem colocados em uma conduta normativa, a qual é afirmada como emancipadora. Se esses sujeitos vivenciarem seus gêneros sem se portarem ou se adequarem à heteronormatividade, serão classificados como errôneos. Por exemplo, trazemos alguns discursos comuns até mesmo aos profissionais da educação. Ao aludirem aos comportamentos de gêneros tidos como inadequados, afirmam: "Isso não é atitude de moça!", "Moça não senta desse jeito e precisa ser organizada!”; nos casos de menino: “Conversa direito, homem não fala dessa forma, essa voz não é de homem!", "Você está fofocando, isso é coisa de menina!". São expressões como essas, baseadas em crenças populares, que demonstram a cultura da heteronormatividade.

Para Balieiro e Risk (2014),

Todo esse contexto fomentou estudos críticos e mais aprofundados sobre a sexualidade que passaram a conceber a perpetuação, a despeito de toda a mudança trazida pelos movimentos sociais, do que se chamou de heteronormatividade. Nesta perspectiva, assume-se que a sexualidade é vivida enquanto uma construção social e histórica. Somos, portanto, frutos do nosso próprio tempo na forma pelo qual concebemos e vivenciamos a sexualidade, que, por sua vez, é construída em meio a relação de poder. A heteronormatividade é um sistema complexo que diferencia aquilo que é "bom” apropriável e saudável do que é moralmente condenável, inapropriado, e deve ser evitado socialmente (p. 160-161).

As categorias e conceitos problematizados vêm nos abrir os olhos para o quanto se torna diversa e extensa a 
classificação das diversidades sexuais e do quanto necessitamos de estudos voltados para essa área a fim de que possamos ter um olhar sobre a especificidade de cada categoria. As travestis, os (as) transexuais e transgêneros, bissexuais, lésbicas e homossexuais são pessoas que se identificam e assumem estilos de vida diferentes da sociedade heteronormativa; com isso, se tornam vítimas constantes da homofobia. Passamos a elucidar abaixo essas categorias.

As pessoas transexuais são as que nascem com o sexo masculino ou feminino, mas não exercem sua identidade de gênero em posição ao seu sexo biológico, assumindo papéis de gênero diferentes daqueles impostos pela sociedade normativa. As pessoas transexuais - tanto transhomens, ou seja, pessoas que nasceram em um corpo feminino, mas se reconhecem como homens, ou as transmulheres, ou seja, pessoas que nasceram em um corpo masculino, mas se reconhecem como mulheres consideram que nasceram em um corpo errado, nesse caso, a biologia não determina a forma como essas pessoas se reconhecem ou se identificam.

A identidade de gênero é isso, a forma como uma pessoa se reconhece, se homem, ou se mulher, independente de um pênis ou uma vagina. Nesse sentido, podemos afirmar que nem todos os homens possuem pênis, e que nem todas as mulheres possuem vagina. A lógica causal determinada pela heteronormatividade de que o corpo biológico define o gênero é, desse modo, falha. Pessoas transexuais, tanto os transhomens quanto as transmulheres, muitas vezes reivindicam cirurgias para mudança de sexo e, juridicamente, a alteração de sua identidade civil.

Já bissexuais são as pessoas que têm desejos e práticas sexuais e relacionamentos afetivos com pessoas de ambos os sexos. Precisamos lembrar que as discussões sobre a lesbianidade e bissexualidade ainda são enfrentam muita discriminação, ao qual se inicia pelo lar e se estende pela escola, ao trabalho e ao mundo social em geral (Brasil, 2013).

Por sua vez, lésbicas são mulheres que se reconhecem como mulheres, mas sentem atração afetiva e sexual por pessoas do mesmo sexo, ou seja, por outras mulheres. As lésbicas, assim como outras categorias da diversidade sexual, não devem ser compreendidas de uma única maneira ou de forma definitiva. Existem diferentes formas de expressão de lesbianidade e de lésbicas, por exemplo, relacionamentos entre mulheres, ambas femininas, ou de um casal lésbico em que uma das mulheres se apresenta de forma mais feminina e a outra mais masculinizada, ou ambas se identificam de forma mais masculinizada.

Mas o que diferencia as lésbicas, por exemplo, dos transhomens, é que elas não se reconhecem como homens. Ainda que algumas gostem de utilizar vestuários e acessórios masculinos, não afirmam de forma categórica que são homens. Já um transhomem, nascido em um corpo feminino, se reconhece como homem, ainda que tenha uma orientação sexual heterossexual (desejar sexualmente mulheres), homossexual (desejar sexualmente homens) ou bissexual (preferências, desejos sexuais e afetivos por ambos os sexos). Por essa razão, como delineia Pamplona (2012), é preferível afirmar que "Não existe o bissexual, a bissexual, assim como não existe a lésbica, o homossexual, a travesti, o (a) transexual, a drag queen, existem sim, travestilidades, homossexualidades, lesbianidades, transexualidades e também bissexualidades” (p. 51).

As travestis nasceram em um corpo masculino e não desejam realizar uma mudança definitiva de seu sexo biológico, embora sintam prazer em performatizar seus corpos em corpos femininos, inclusive, exagerando em indumentárias e adotando implante de silicones, cirurgias estéticas e uso carregado de maquiagens e esmaltes. Podemos dizer que as travestis potencializam ao máximo a expressão da feminilidade, contudo, sem repudiar seu órgão genital masculino. Em alguns casos, podemos dizer que existe um limite tênue entre as travestis e as transmulheres. Wiliam Siqueira Peres (2009) define

as travestis como pessoas que se identificam com a imagem e o estilo feminino, apropriando-se de indumentárias e adereços de sua estética, realizando com frequência a transformação de seus corpos, quer por meio da ingestão de hormônios, quer através da aplicação de silicone industrial e das cirurgias de correção estética e de próteses. As transexuais são pessoas com demandas de cirurgias de mudança de sexo e de identidade civil, demandas que não encontramos nas reivindicações emancipatórias das travestis. Já as transgêneros são pessoas que se caracterizam esteticamente por orientação do gênero oposto, não se mantendo o tempo todo nesta caracterização, como o faz as 
travestis e as transexuais. Como exemplos destas últimas podemos elencar as/os transformistas, as drags queens, os drag kings etc (p. 236).

Portanto, os travestis são pessoas que se caracterizam esteticamente pelo gênero oposto, não sendo estável o tempo todo. Dessa forma, para Peres (2009),

A construção de uma cultura de resistência e o encontro com o poder, vivenciados pelas travestis brasileiras, mostramse como consequência da organização social e política dessa comunidade, que cada vez mais tem participado de conselhos municipais, estaduais e federais, levando as reivindicações de suas companheiras e propondo saídas para o enfrentamento dos estigmas e das discriminações tão intensamente vividos por milhares de travestis e transexuais em todo o território nacional. Com essas reflexões preliminares pretendo contribuir para a desconstrução dos estigmas e dos preconceitos experimentados por essa comunidade e incentivar a promoção de espaços de discussões e agendas de pesquisas e estudos que possam colaborar para a promoção da saúde, dos direitos humanos e da construção da cidadania enquanto direito de participação social e política nas tomadas de decisões da sociedade como um todo (p. 244).

Tal multiplicidade de expressões de gênero e sexuais nos mostra como as naturalizações e essencialismos biológicos se constituem como processos discriminatórios, pois diante de variadas expressões, cada pessoa deve ser vista em sua singularidade e multiplicidade de ser. As diferenças devem ser respeitadas em suas múltiplas faces e possibilidades de configuração, conforme o artigo $5^{\circ}$ da Constituição Federal de 1988, que diz: "Todos são iguais perante a lei, sem distinção de qualquer natureza, garantindo-se aos brasileiros e aos estrangeiros residentes no País a inviolabilidade do direito à vida, à liberdade, à igualdade, à segurança e à propriedade [...]” (Brasil, CF/1988). Nessa direção,

A escola deve ser também um espaço de formação de cidadania e de respeito aos direitos humanos, assim as (os) docentes devem ser encorajados a assumir sua responsabilidade no combate a todas as formas de preconceitos e discriminação que permeiam o espaço escolar. A navalha de Occam de educadores e educadoras, baseada no princípio da pluralidade sexual desnecessária, exclui do currículo as representações de mundo de estudantes gays, lésbicas, bissexuais, travestis e transexuais, que resistem à matriz normatizante da sexualidade branca, ocidental, de classe média e heterossexual. Mas não podemos esquecer que navalhas também podem ser usadas no assassinato das minorias sexuais no Brasil, o que pode fazer de educadoras e educadores sutis amoladores de navalha diplomados e especializados. (Dinis, 2011, p. 49)

Então, diante do que foi levantado, são necessárias análises constantes de novas reflexões e diálogos, para que possamos compreender que os valores heterossexuais não são os únicos, tampouco os melhores, são valores que devem ser equivalentes de direito com outros inúmeros valores e vivências sexuais e de gênero.

Considerando gênero como constituinte da forma identitária do indivíduo, os estudos aqui realizados procuram explicá-lo a partir das lutas libertárias ocorridas por uma posição igualitária e justa. Em meados de 1960, o gênero masculino era visto como absoluto e insubstituível pelo gênero feminino; no entanto, foi também nesse período que o gênero feminino foi aos poucos ocupando seu espaço, quando surgiram questionamentos em relação ao conceito da sexualidade, apresentando-a também como fonte de prazer e não exclusivamente para reprodução humana. O movimento feminista surgiu nesse bojo, para desmistificar e ampliar a posição do gênero feminino diante da sociedade, tornando as mulheres cidadãs pensantes que resolveram lutar por seus direitos e que Segundo Beleli (2014) esses movimentos estão relacionados as transformações sociais, econômicas e os valores culturais, uma vez que, o padrão das mulheres como moças comportadas e virgem foi rompido onde o destino final e necessário era a maternidade, desafiando convenções de gênero.

Deste modo, essas lutas e transformações culturais do gênero feminino consolidam novas ideias, contrárias à regra padrão da cultura estabelecida mundialmente, em que o gênero feminino era submisso ao gênero masculino. Nos estudos sobre a condição feminina, o feminino era visto como propriedade privada do masculino, pois foi constituído em uma ideologia 
patriarcal. De acordo com Miriam Pillar Grossi (1998), a definição de gênero propicia dificuldades no senso comum com reflexão nas preocupações da teoria feminista, separar a problemática da identidade de gênero e a sexualidade, esta marcada pela escolha do objeto de desejo. Nesse viés, o conceito de gênero é constitutivo a partir da identidade do indivíduo; seria ele o sexo socialmente construído, ou seja, esse gênero masculino ou feminino, numa aproximação mais específica, pode ser transitório, pois, em uma determinada condição, pode sofrer transformações, tornando-se, às vezes, conflitantes.

Esses conflitos apontam para o surgimento histórico das discriminações ou preconceitos que fundamentam o gênero masculino, compreendido como detentor de condições específicas do trabalho referente à mão de obra, predominando o machismo em diferentes instâncias de trabalho, na qual os papéis de homens e mulheres eram bem definidos. Nesse espaço, a mulher seria o indivíduo submisso ao homem, tornando-se obrigada apenas aos afazeres domésticos e funções maternas.

Para a estudiosa Pelúcio (2014), essa naturalização do gênero influencia e organiza a vida de todos, e sua presença já se torna aparentemente natural quanto a seus efeitos. Com isso precisamos desnaturalizar essa concepção:

Desnaturalizar é pensar que gênero, esta marca fundamental da nossa existência, não é um dado biológico e pronto, mas varia de sociedade, ao longo da história, e só pode ser entendido na sua dimensão política, sim, política, porque tem a ver com relações de poder: quem manda, quem obedece, o que é verdade, o que não é. Enfim, para a gente poder entender o gênero em toda a sua dimensão social, é preciso relacionar gênero com raça/etnia, classe social, pertencimento de geração, entre outras marcas de direção social (Pelúcio, 2014, p.100).

A desnaturalização desse conceito já estabelecido, fundado, conhecido e de transformação resistente, não é um processo fácil. Requer que se mexa em algo que poderia ser contraditório e diverso, pois os gêneros femininos ou masculinos são conhecidos a partir de uma determinada classificação desde o nascimento. Os indivíduos atribuídos ao gênero masculino e feminino em seu nascimento são padronizados como homem e mulher, buscando uma compatibilidade com sua genitália biológica. Com isso, a sociedade não aceita que um indivíduo considerado como macho, do sexo masculino, reconhecido como homem, se desvie das atribuições padronizadas para seu gênero. O mesmo podemos dizer em relação ao gênero feminino. As famílias, assim como diferentes instituições, passam a apontar aqueles que fogem do padrão de gênero pré-estabelecido pela sociedade e muitas vezes rejeitam os membros que fogem a esse padrão. Para o autor Silva (1999), a própria ciência já apresenta essa normatividade de gênero, o que dificulta ainda mais esse processo de desnaturalização.

A sociedade está feita de acordo com as características do gênero dominante, isto é, o masculino. Na análise feminista, não existe nada de mais masculino, por exemplo, do que a própria ciência. A ciência reflete uma perspectiva eminentemente masculina. Ela expressa uma forma de conhecer que supõe uma separação rígida entre sujeito e objeto. Ela parte de um impulso de dominação e controle: sobre a natureza e sobre os seres humanos. Ela cinde corpo e mente, cognição e desejo, racionalidade e afeto. Essa análise da masculinidade da ciência pode ser estendida para praticamente qualquer campo ou instituição social (Silva, 1999, p. 93-94).

Desse modo, o gênero masculino é reconhecido pela ciência como absoluto e intocável e, em toda a existência dos indivíduos fabricados e normatizados de acordo com sua religião, família, etnia e raças, usa-se de seu próprio conceito como exemplo do certo. Essas características são estabelecidas como prontas e acabadas pela ciência e suas denominações. A sociedade recebe essa naturalização como verdade estabelecida e inquestionável, devendo assim ser seguida. Argumenta Pelúcio (2014) que essa dimensão normativa e padronizada na vivência dos gêneros se operacionaliza constantemente nos mais variados segmentos da sociedade, assim como encontra no espaço escolar um território para afirmação dessa naturalização dos gêneros, ou, ao contrário, para sua subversão.

Nos diferentes espaços da escola, como a sala de aula, o pátio e os banheiros, percebemos como se realiza uma pedagogia de gênero, a qual busca coordenar olhares, moldar condutas e arquitetar a educação de nossos corpos. Evidentemente, essa pedagogia não é neutra, tampouco desinteressada; ela é um campo de poder que atua para confirmar e 
balizar a naturalização dos gêneros, iniciada desde o nascimento do sujeito. A escola, como um carimbo, afirma constantemente o que é e o que deve ser pertencente ao universo feminino e masculino, realizando uma vigilância constante para que essas barreiras não sejam ultrapassadas, mescladas ou borradas.

Conforme Louro (1997),

Se as diferentes instituições e práticas sociais são constituídas pelos gêneros (e também os constituem), isso significa que essas instituições e práticas não somente "fabricam" os sujeitos como também são, elas próprias, produzidas (ou engendradas) por representações de gênero, bem como por representações étnicas, sexuais, de classe, etc. De certo modo poderíamos dizer que essas instituições têm gênero, classe, raça. Sendo assim, qual o gênero da escola? (Louro, 1997, p. 88).

O educador é normatizador de corpos, ou seja, ele busca reafirmar nos corpos seus lugares dados no nascimento por uma atribuição biológica. Assim, um corpo feminino deve permanecer atrelado ao universo feminino (com suas vestes, cores, acessórios, trabalhos, tarefas, jogos, brincadeiras, linguagem). Por outro lado, um corpo masculino deve transitar apenas dentro do universo demarcado como específico e particular dos códigos masculinos.

Para a autora Pelúcio (2014), o gênero é constituído e consolidado em duas vertentes simbólicas: a corrente essencialista e a construtivista. A essencialista é representada e entendida desde que nascemos em uma essência pronta e acabada, que não pode ser mudada. Já a construtivista seria o oposto, construída de acordo com o ambiente em que se vive. Observamos, assim, que tudo foi reescrito culturalmente, ou seja, fomos aos poucos ensinados a ler e compreender esses signos. É em função dessa demanda naturalizada da questão gênero, e diante de uma tentativa de modificação do que está posto, que surgem reivindicações por direitos identitários, civis, culturais e de importantes relevâncias. Surge, a partir daí, o próprio conceito de gênero. -Segundo Grossi (1998),

Gênero é uma categoria usada para pensar as relações sociais que envolvem homens e mulheres, relações historicamente determinadas e expressas pelos diferentes discursos sociais sobre a diferença sexual. Gênero serve, portanto, para determinar tudo que é social, cultural e historicamente determinado. No entanto, como veremos, nenhum indivíduo existe sem relações sociais, isto desde que se nasce. Portanto, sempre que estamos referindo-nos ao sexo, já estamos agindo de acordo com o gênero associado ao sexo daquele indivíduo com o qual estamos interagindo (p.5).

Assim, a partir do momento que nos relacionamos e interagimos socialmente, já estamos atuando de acordo com o que foi determinado historicamente para cada gênero. As mais diferenciadas experiências sociais reforçam recorrentemente os lugares marcados e tidos como certos para cada gênero. Ou seja, menino tem que ter traços e gestos masculinos; menina traços e gestos femininos. Se acontecer de um indivíduo do sexo masculino apresentar-se com traços ou gestos femininos, ele será automaticamente reprimido ou rejeitado pela família ou pela sociedade e sofrerá os atos de discriminação e preconceito por seu desvio de gênero. Conforme a autora Moreno (1999),

Quando meninos e meninas chegam à escola, já têm interiorizado a maioria dos padrões de conduta discriminatória. Mesmo que tenhamos escolas mistas e que meninas e meninos se sentem ao redor das mesmas mesas, na hora do recreio os meninos jogam com os meninos e as meninas com as meninas. Nas brincadeiras livres é que se exercitam espontaneamente os modelos aprendidos de conduta, é aí que aparece a fantasia com a qual cada indivíduo se identifica. Mas, curiosamente, é nesses momentos de "liberdade" que cada indivíduo se encontra mais intensamente limitado pelas normas estabelecidas, como se tivesse "plena liberdade" para identificar-se com os arquétipos que estão destinados a ele em função de seu sexo, mas não para transgredi-los (p. 30-32).

Percebe-se que há uma tentativa em colocar cada indivíduo exatamente no seu lugar, e essas tentativas são guiadas por condutas muitas vezes espontâneas. Agimos com palavras, gestos e até mesmo policiando detalhes dos dois gêneros, buscando 
demarcar e diferenciar o que cabe a cada gênero, se ao feminino, se ao masculino.

Reforçamos mais uma vez que o sexo feminino foi sempre desfavorecido em relação ao sexo masculino, sendo preciso travar uma luta por conquistas e direitos constantes ao longo da história. Não por acaso, ainda em pleno século XXI, as mulheres são menos representadas no mundo da política do que os homens; recebem salários mais baixos, mesmo exercendo as mesmas funções; são assediadas quando ocupam cargos de poder, especialmente no cenário político; são violentadas e espancadas por seus companheiros; têm seus corpos objetificados e comercializados como mercadorias, direta e indiretamente. Por exemplo, basta observarmos comerciais de televisão, letras de músicas, novelas, publicidades, para vermos o quanto a mulher é tratada como um corpo a ser exibido, mostrado e comercializado.

Diante desses fatos, que ocorrem desde a infância, tanto no âmbito escolar, quanto no âmbito familiar, ou em outras esferas institucionais, percebemos que os gêneros são tratados como pontos estáveis e imutáveis, quando na verdade são aprendidos todos os dias. São, assim, flexíveis, maleáveis, capazes de se refazerem e remodelaram. Ser homem e ser mulher não é algo fixo, é uma atuação diária de afirmação.

Por sua vez, quando falamos em identidade de gênero, o próprio termo nos permite compreender essa categoria. Identidade se refere àquilo que faz um sujeito, um objeto ser o que é, e não outra coisa. Portanto, identidade de gênero se refere à forma como uma pessoa se identifica, se homem, ou se mulher. Mas o leitor poderia indagar qual o motivo em se falar em identidade de gênero, quando temos a categoria gênero. E a resposta é justamente o que colocamos e exploramos no item anterior. $O$ gênero não é necessariamente assegurado em decorrência da genitália do sujeito. $O$ gênero não é dado biologicamente. Nesse sentido, devido ao gênero não ser uma instância fixa, natural e imutável, a forma como cada pessoa se identifica não é ocasionada em decorrência de possuir determinado órgão genital. Logo, podemos dizer que o que leva uma pessoa a se reconhecer como homem ou mulher é um processo de identificação que ocorre ao longo da constituição da própria pessoa como ser humano; assim, o que está em questão não é obrigatoriamente a biologia.

$\mathrm{Na}$ constituição da nossa identidade de gênero, isso nos remete a nos questionarmos: qual é a minha identidade? O que sou? Como me vejo? Como verdadeiramente me sinto? Esses e outros questionamentos surgem durante o processo de conhecimento de identidade de gênero, portanto, identidade de gênero diz respeito à forma como a pessoa se reconhece. Uma pessoa pode nascer em um corpo tradicionalmente considerado masculino, mas se afirmar e se reconhecer como mulher. Nesse caso, a identidade de gênero dessa pessoa não coincide com seu corpo biológico. Esse exemplo, conforme discorremos no capítulo anterior, trata de uma transmulher.

É indispensável destacarmos que a identidade de gênero não tem relação obrigatória e fixa com a orientação sexual da pessoa, ou seja, não diz se a pessoa possui interesse sexual e afetivo por homens, mulheres, ou por ambos os sexos. Por exemplo, podemos ter um transhomem (a pessoa que nasceu em um corpo feminino, mas se identifica como homem identidade de gênero masculina) e sua orientação sexual pode ser homossexual, heterossexual ou bissexual. Nesse caso, se um transhomem tiver interesse sexual por um homem, o senso comum diria que ele é heterossexual, pois nasceu com um corpo feminino. No entanto, isso seria um equívoco, pois o que se deve observar é a identidade de gênero, se essa pessoa se reconhece como homem, ainda que tenha uma vagina e interesse sexual e afetivo por homens. Assim, essa pessoa é um transhomem gay, ou um transhomem homossexual. Para Louro (1997),

A pretensão é, então, entender o gênero como constituinte da identidade dos sujeitos. E aqui nos vemos frente a outro conceito complexo, que pode ser formulado a partir de diferentes perspectivas: o conceito de identidade. Numa aproximação às formulações mais críticas dos Estudos Feministas e dos Estudos Culturais, compreendemos os sujeitos como tendo identidades plurais, múltiplas; identidades que se transformam, que não são fixas ou permanentes, que podem, até mesmo, ser contraditórias (p.24).

Gênero e sexualidade são aprendizados sociais passíveis de transformação e de combinações às vezes consideradas 
contraditórias. As identidades, não apenas as de gênero, se transformam ao longo da vida. Não nascemos prontos e acabados. Gostamos de ter a ilusão que somos médicos (as), professores (as), cantores (as), que somos pai/mãe, que sabemos isso ou aquilo, mas tudo isso é passível de mudança, assim como nossos corpos, nossas múltiplas identidades, e por que não, nosso próprio gênero, nossa orientação sexual. A certeza é uma ilusão muitas vezes desmentida em nossas vidas. Desse modo, o sujeito se identifica social e historicamente como feminino ou masculino, e assim constitui sua identidade de gênero de forma plástica, maleável, desmontável e, talvez, podemos arriscar a dizer como uma obra de arte.

Grossi, considera que (1999)

Este núcleo de nossa identidade de gênero se constrói em nossa socialização a partir do momento da rotulação do bebê como menina ou menino. Isto se dá no momento de nascer ou mesmo antes, com as novas tecnologias de detectar o sexo do bebê, quando se atribui um nome à criança e esta passa a ser tratada imediatamente como menino ou menina. A partir deste assinalamento de sexo, socialmente se esperarão da criança comportamentos condizentes a ele (p. 8)

Portanto, essa tentativa de produzir ou tentar afirmar uma identidade de gênero se inicia muito antes do nascimento do indivíduo e, por meio da ciência e suas tecnologias, essa afirmação é feita a partir da visualização da ultrassonografia ou por outros meios de tecnologia. Essas identidades estão sempre se relacionando com as nossas linguagens e práticas específicas, as quais fomos ensinados. A tentativa e esforço ao atribuir um gênero no nascimento do sujeito é evitar que ele se identifique com um gênero que não corresponda a sua genitália, a seu corpo biológico, já que as identidades estão sempre em constante construção. Sendo instáveis, elas podem sofrer ou experimentar modificações. Na atribuição do sexo do bebê e de seu gênero, gera-se a normatização de seu corpo. Então, antes mesmo desse nascimento, a identidade começa a ser afirmada, não pelo sujeito, mas pelos aparatos a sua volta socialmente reconhecidos. Uma criança que venha a ter uma conduta diferente da qual é constituída e ensinada pela sociedade é forçada a se estabelecer em instâncias disciplinares cotidianas que a conduzirão a colocar-se nas normas as quais se julgam apropriadas.

Segundo Moreno (1999),

a partir do momento em que nascemos, começamos a receber essa influência social que condicionará nossa maneira de ver e de estar no mundo. Com a linguagem, aprendemos a primeira forma de dividir nosso universo em categorias. As palavras denominam as coisas, mas também fazem com que as agrupamos de uma determinada maneira em nosso pensamento. O bebê aprende com as primeiras palavras que existe uma "mamãe" e um "papai"; logo aprenderá que existem "meninas" e "meninos", e esta dicotomia o terá diferenciado muito antes que ele saiba que existe a palavra "pessoa", que aplicar-se igualmente a todas elas. Existem muitas formas de diferenciar as pessoas, mas nosso idioma priorizou a característica sexo para subdividi-las, dando-lhe um nome específico. Evidentemente, o mesmo não ocorre com outras características humanas. Não existe, por exemplo, uma palavra específica para denominar uma pessoa de olhos azuis ou cujos pés suam. (p. 14).

Portanto, a sociedade e o estado, junto a suas instituições, geram a normatização de corpos de meninos (as) quando reforçam a vivência do gênero atribuído no nascimento e buscam impedir a vivência de uma identidade de gênero oposta ao sexo biológico.

E para separar a criança, sendo ela menino (a) que gosta de brincadeiras que não correspondam ao seu gênero de nascimento, o educador e seus pais tentam normatizar esses desejos; no entanto, eles não são esclarecidos de que o fato de gostarem de brincadeiras, acessórios ou relacionamento social com meninas ou meninos são detalhes que não influenciarão na escolha sexual do filho ou do aluno na sua vida adulta. Para conceituar o papel de gênero, um exemplo simples seria o próprio exercício ou atuação em relação àquilo que é esperado para cada gênero, masculino e feminino. Seria tudo que cada gênero faz na tentativa de corresponder ao que se espera social, histórica e culturalmente.

O homem inserido na sociedade é um representante do papel masculino; a mulher seria a representante do papel 
feminino. Por sua vez, esses papéis mudam ao longo da história e de cada cultura. Por exemplo, à mulher não era permitido até pouco tempo dirigir automóveis ou trabalhar fora de casa; hoje esse papel já é aceitável. Na cultura ocidental, em sua maioria, usualmente não cabe ao homem o uso de saias, vestidos, mas em alguns países do ocidente esse é um papel atribuído a eles. Nesse mesmo viés, Grossi (1998) compreende que

Papel é aqui entendido no sentido que se usa no teatro, ou seja, uma representação de um personagem. Tudo aquilo que é associado ao sexo biológico fêmea ou macho em determinada cultura é considerado papel de gênero. Estes papéis mudam de uma cultura para outra. A antropologia, que tem como objetivo estudar a diversidade cultural humana, tem mostrado que os papéis de gênero são muito diferentes de um lugar para o outro do planeta (p. 6).

O que a autora destaca é que, sendo o homem ou a mulher membros constituintes de uma determinada sociedade, dependendo da região e de sua cultura, suas representações de papel mudam. Existem culturas em que esses papéis são representados de maneiras totalmente diferentes, portanto, nas instituições, os papéis são nomeados em masculinos e femininos. Tradicionalmente, é posto que meninas gostam de rosa, meninos de azuis, meninas brincam de bonecas e de brincadeiras mais calmas e têm que se comportar e ter atitudes adequadas ao se sentar; já os meninos brincam de carrinhos, gostam de brincadeiras mais agitadas e não são estimulados a se sentarem de maneira correta. Meninos são rotulados como agressivos, desordeiros, indisciplinados; meninas devem ser meigas, delicadas, frágeis, serenas, calmas e submissas. Esses papéis de gênero são estabelecidos como cultura predominante na produção e reprodução da sociedade, escola, família, em que se estabelecem e transportam as normas dos papéis existentes na sociedade.

Segundo Foucault (2014):

Nessas estratégias, de que se trata? De uma luta contra a sexualidade? De um esforço para assumir seu controle? De uma tentativa de melhor regê-la e ocultar o que ela comporta de indiscreto, gritante, indócil? De uma maneira de formular, a seu respeito, essa parte de saber que poderia ser aceitável ou útil, sem mais? De fato, trata-se, antes, da própria produção da sexualidade. Não se deve concebê-la como uma espécie de dado da natureza que o poder é tentado a pôr em xeque, ou como um domínio obscuro que o saber tentaria, pouco a pouco, desvendar. A sexualidade é o nome que se pode dar a um dispositivo histórico: não à realidade subterrânea que se apreende com dificuldade, mas à grande rede da superfície em que a estimulação dos corpos, a intensificação dos prazeres, a incitação ao discurso, a formação dos conhecimentos, o reforço dos controles e das resistências encadeiam-se uns aos outros, segundo algumas grandes estratégias de saber e de poder (p. 115).

Portanto, fica evidente o quanto o poder de reger e nomear as espécies de acordo com suas normatizações se estabelece em pautas através de suas posições pré-estabelecidas no decorrer de seu histórico social. Compreendemos não ser de hoje, mas de muito tempo atrás, que todo o contexto que envolve diversidade de gênero foi concebido a uma vedação escura nos olhos da sociedade. Em consequências, surge a necessidade de controlar um assunto que deveria ser tratado como natural, mas é visto como um dispositivo que requer controle total.

\section{Diversidade de Gênero e Ensino Superior}

As análises realizadas nas matrizes curriculares dos cursos de graduação da UFJ foram de fundamental importância para evidenciar a maneira que a temáticas desta pesquisa são abordadas nos diferentes currículos. Essas discussões, muito presentes hoje também nos diversos âmbitos da sociedade, devem ser debatidas, sobretudo, nos espaços acadêmicos, a partir de um embasamento teórico, o que nos desperta para a necessidade de termos referentes acerca das problematizações levantadas ao longo deste estudo. É necessário que se faça presente nos conteúdos curriculares e que envolva docentes e discentes, discutindo essa temática de maneira simples e não discriminada, pois o assunto é extremamente pertinente em todas as camadas sociais. 
Os cursos devem oferecer, em seus eixos curriculares, propostas que dispõem de informações que envolvam as condições dos indivíduos que são pertencentes a diversas classificações de gênero. Isso tudo para que se possa referir ao assunto de forma fundamentada e que oriente as instituições sociais, de maneira a contribuir com a resolução das problematizações da escola que, até então, tem sido reprodutora de papéis de gênero normativos, desqualificando e negando as identidades de gênero diversas. Abaixo, vamos detalhar um pouco mais como se encontram as matrizes dos cursos selecionados para esta pesquisa.

\subsection{Curso de Licenciatura em Geografia}

O curso de Geografia foi implementado no Campus Avançado do município de Jataí, adaptado com as extensões numa política de interiorização. São oferecidas duas modalidades, licenciatura e bacharelado. Sua matriz contribui com discursos que falam da nossa atuação no espaço e nossa autonomia inerente ao ambiente, bem como gênero, identidade e fronteiras. Conforme o Quadro 1, o Projeto Político Pedagógico do Curso foi reformulado/atualizado em 2017:

Quadro 1: Dados Gerais do PCC do Curso de Licenciatura em Geografia.

\begin{tabular}{|c|c|c|c|}
\hline Ano PPC & Carga Horária & Número de Vagas & Duração \\
\hline 2017 & 3.208 & 20 (vinte) & 4 anos \\
\hline
\end{tabular}

Fonte: UFJ (PPCs dos cursos).

Ao realizar a busca de palavras na matriz curricular do curso de Licenciatura em Geografia, não foram encontradas nenhuma das palavras-chave utilizadas na pesquisa. Porém, encontraram-se outras palavras que se aproxima em disciplinas optativas, mesmo que em certa distância das palavras-chave, como "Sujeito", "Cultura", "Espaço e poder"; "Espaço e diferença"; "Geografia e cidadania"; "Sujeito e consciência do espaço"; "Estado, diversidade e movimentos sociais territoriais (habitação e terra)", entre outras. Ainda que de caráter optativo, as disciplinas trazem temas que abrangem uma dimensão essencial.

Em sua referência bibliográfica, foi encontrada a seguinte referência: Albuquerque, U. P. de; Alves, A. G. C.; Araujo, T. A. de S. Povos e paisagens: etnobiologia, etnoecologia e biodiversidade no Brasil. Recife: NUPEEA/UFRPE, 2007. 148 p. Com isso, refletimos que a diversidade é um conceito de ramificações e multiplicidade, tendo a visão de heterogeneidade, variedade, costumes e vivências, sendo existente entre distintos grupos de uma sociedade com entes diferentes que querem ser aceitos dessa forma.

A partir dessa reflexão, concluímos que o educador é a segunda pessoa de referência para os educandos, com quem irão estabelecer contato, um vínculo de confiança fora do seu círculo familiar, e com quem irão conversar com franqueza, dependendo da reciprocidade desse educador. Vivenciarão assuntos que, para ambos, serão variados e, no decorrer do tempo, esses professores contribuirão para construir suas referências, tornando, para eles, alguém em quem possam confiar, mesmo que não tenham a mesma opinião. Sendo assim, a escola é o lugar de desconstruir aquilo que está posto como natural, como verdades cristalizadas, as quais não são questionadas ou colocadas em confronto.

\subsection{Curso de Licenciatura em Matemática}

O curso de licenciatura em Matemática é oferecido na Regional Jataí da Universidade Federal de Goiás desde 1980, implantado como definitivo em 1996. Tem sua importância para a formação de professores que visam ensinar a disciplina de matemática. Além de formar professores que atuam nas diferentes áreas de ensino na rede pública e privada, também insere alguns desses formandos em diversos ramos da indústria e em repartições públicas. Conforme o Quadro 2, o Projeto Político 
Pedagógico do Curso de Licenciatura em Matemática é oferecido pela Universidade Federal de Jataí e foi atualizado no ano de 2018.

Quadro 2: Dados Gerais do PCC do Curso de Licenciatura em Matemática.

\begin{tabular}{|c|c|c|c|}
\hline Ano PPC & Carga Horária & Número de Vagas & Duração \\
\hline 2018 & 3304 horas & 45 vagas anuais & \\
\hline
\end{tabular}

Fonte: UFJ (PPCs dos cursos).

O objetivo do curso é a formação de profissionais que sejam capazes de transcender as dificuldades necessárias e complexas que a educação básica e o ensino de jovens e adultos almejam. O curso é oferecido no período vespertino, com duração mínima de oito semestres e a máxima de quatorze semestres. Ao final do curso, garantirá ao licenciado condições para assumir sua função na área profissional, a liberdade, a consciência e a compreensão, além de ter bom senso sócio-políticocultural, que é próprio do universo docente.

Considerando as palavras-chave desta investigação, nenhuma foi encontrada no PPC do curso de Licenciatura em Matemática, observando assim que o referido curso não oferece em suas disciplinas obrigatórias ou mesmo optativas de núcleo livres disciplinas que venham embasar a temática de gênero em seu currículo. Esses alunos têm uma carga horária, conforme Quadro 02, bastante extensa para sua efetivação profissional. No entanto, ainda que o curso de matemática esteja localizado na área de exatas, os educandos partilham de maneira direta ou indireta com essas problematizações da diversidade no ambiente educacional.

É, portanto, de extrema relevância o embasamento teorizado do tema diversidade de gênero que, hoje, graças aos estudos e seus avanços epistemológicos, traz para a atualidade diversas teorias que desmistificam e esclarecem o referente tema em diversos aspectos que parecem ser ignorados há muito tempo pela educação junto à sociedade.

\subsection{Curso de Licenciatura em Pedagogia}

Em meados 1980, ainda no mandato do reitor José Cruciano de Araújo, o curso de pedagogia estava sendo consolidado. Os pedagogos são profissionais que atuam em várias áreas na educação e em seus diferentes níveis da educação. O curso se destina a profissionais que irão atuar na educação infantil e anos iniciais do ensino fundamental; esses profissionais se aprofundam na dinâmica do conhecimento da sociedade e da educação como realidade concreta de nosso contexto social. Seguem os dados do curso de Licenciatura em Pedagogia no Quadro 3, apresentado abaixo:

Quadro 0: Dados Gerais do PCC do Curso de Pedagogia.

\begin{tabular}{|c|c|c|c|}
\hline Ano PPC & Carga Horária & Número de Vagas & Duração \\
\hline 2003 & 3.120 & 80 vagas & 4 anos \\
\hline
\end{tabular}

Fonte: UFJ (PPCs dos cursos).

A Pedagogia se define como investigativa da natureza. Sua finalidade na educação é a de trazer princípios em que o profissional atuará em diversas instâncias sobre prática e investigação, lidando diretamente com fatos e estruturas que processem a problematização referente à educação em seus níveis e modalidades. Com isso, foram encontradas na matriz de pedagogia nos cursos de núcleo livre quatro temáticas que têm certa aproximação à diversidade: "Educação e diversidade étnico-racial"; "Trabalho, relações de gênero e saúde"; "Educação não formal: O processo educativo em diferentes espaços e 
manifestações da cultura"; "Violência de gênero"; "História, Educação e diversidade étnica e cultural"; "Sexualidade e constituição da subjetividade".

É preciso destacar que os profissionais do curso vão ter contato diário com o indivíduo desde a primeira infância, momento em que a criança construirá uma base que a beneficiará por toda a vida, ou seja, uma fase em que o indivíduo vai se constituindo como ser humano, portanto, é imprescindível que os profissionais tenham conhecimento sobre temas como "diversidade", "sexualidade", "teoria queer", "identidade", "gênero", "discriminação" e "diferenças".

A contextualização do tema na formação superior em curso de Pedagogia trará amparo na sua difusão a partir da Educação Infantil. A exploração do tema na formação acadêmica em licenciaturas voltadas às escolaridades seguintes estaria preparando profissionais que contribuirão com os indivíduos no enfrentamento dessa problemática e, ao mesmo tempo, conseguirão acolher e restaurar as vítimas que estão em batalhas contínuas com o preconceito. Isso porque o enfrentamento à homofobia está dentro dos muros da escola e fora deles, pois o mundo é extremamente rude com a diversidade.

\subsection{Curso de Licenciatura em Ciências Biológicas}

O curso teve início em dezembro de 1979, tendo como missão capacitar profissionais para atuarem na docência no Ensino Superior, visando, assim, os processos científicos sociais e ambientais e a preparação de seus educandos para atuarem na educação. Esses profissionais necessitam compreender a natureza, o surgimento biológico e o papel da escola e suas práticas pedagógicas para o conhecimento e alcance de seus aprendizados de forma crítica e reflexiva. De acordo com os dados disponibilizados na página eletrônica da Universidade Federal de Jataí, o Projeto Político Pedagógico do Curso de Licenciatura em Ciências Biológicas foi atualizado no ano de 2017, conforme Quadro 4.

Quadro 4: Dados Gerais do PCC do Curso de Biologia.

\begin{tabular}{|c|c|c|c|}
\hline Ano PPC & Carga Horária & Número de Vagas & Duração \\
\hline 2017 & 3760 & 30 vagas & 6 anos \\
\hline
\end{tabular}

Fonte: UFJ (PPCs dos cursos).

O estudante em Ciências Biológicas deve estar preparado para a aplicação pedagógica do conhecimento e para as experiências da biologia, atuando como educador no ensino fundamental, médio, tecnológico e superior. Além disso, irá desenvolver e executar projetos socioeconômicos que envolvam o descobrimento de novos conhecimentos e tecnologias.

O Curso de Licenciatura em Ciências Biológicas envolve o estudo sobre as diferentes formas de vida e necessita da sensibilidade em abranger a dimensão do indivíduo como ser social digno de respeito na forma em que se reconhecem. Por conta disso, o curso trouxe em sua matriz curricular, na seção "Habilidade do Egresso" (item 5.3), o reconhecimento das formas de discriminação racial, social, de gênero, etc. que se fundem inclusive em alegados pressupostos biológicos, posicionando-se diante delas de forma crítica, com respaldo em pressupostos epistemológicos coerentes e na bibliografia de referência. Mas, nas suas ementas, não foi apresentada nenhuma disciplina que tratasse da temática.

É preciso destacar que o tema diversidade de gênero e suas ramificações se tornaram extremamente relevantes, pois ultrapassam todas as dimensões que vão além das paredes escolares, familiares e sociais. Por mais que as instituições, os educadores, as famílias e a sociedade ignorem os indivíduos pertencentes a essas classificações e fingem não perceber essas identidades, eles (as) continuarão presentes. Suas classificações se distinguem de diversas maneiras e alguns afrontam as socializações em que estão inseridos como forma de exigir sua aceitação e respeito perante a família e a sociedade. É de extrema urgência a discussão do tema nas universidades, com a implantação de disciplinas curriculares que venham 
desmistificar e contextualizar a condição heterogênea, pois o tema é vasto e sempre se fez presente nas nossas socializações.

\subsection{Curso de Licenciatura em História}

O curso de História da UFG-Jataí teve sua origem em 2006 dentro do programa de expansão das Instituições. Seu objetivo é o de contribuir para a redução das desigualdades regionais, promovendo, assim, a inclusão social e sua cidadania. De acordo com os dados disponibilizados na página eletrônica da Universidade Federal de Jataí, o Projeto Político Pedagógico do Curso de Licenciatura em História foi atualizado no ano de 2017, conforme Quadro 5.

Quadro 5: Dados Gerais do PCC do Curso de História.

\begin{tabular}{|c|c|c|c|}
\hline Ano PPC & Carga Horária & Número de Vagas & Duração \\
\hline 2012 & 2.992 horas & 50 vagas & 4 anos \\
\hline
\end{tabular}

Fonte: UFJ (PPCs dos cursos).

O perfil desse profissional requer formação solidária na área de História, além do domínio no processo de produção do conhecimento histórico e suas perspectivas. Com isso, deve ter conhecimento de suas metodologias aplicadas no exercício pedagógico, defendendo a melhoria do ensino e intervindo na realidade escolar.

O curso de História vem complementar os discursos que falam da nossa autonomia inerente ao ambiente, bem como gênero, identidade e fronteiras, mas sempre baseando-se em contextos históricos. Isso tudo visando condições que operem para a dicotomia do momento em que vivemos com suas transformações e descobertas.

Há referência a dois livros, sendo um deles de bibliografia básica (FUNARI, Pedro Paulo et al. (Org.). Amor, Desejo e Poder na Antiguidade. Relações de gênero e representações do feminino. Campinas: Unicamp. 2003.) e o outro como bibliografia complementar (MATTOS, Regiane Augusto. História e cultura afro-brasileira. São Paulo: Contexto, 2008).

\subsection{Curso de Licenciatura em Física}

O curso iniciou suas atividades em agosto de 2016 e o oferecimento de seu período é predominantemente noturno. É ofertada aos acadêmicos em Física uma sólida formação pedagógica, habilitando-os para atuarem na área educacional. Assim sendo, foi detectada a necessidade específica em tornar sua estrutura curricular mais adequada às necessidades educacionais. Algumas informações adicionais estão dispostas no Quadro 6:

Quadro 6: Dados Gerais do PCC do Curso de Física.

\begin{tabular}{|c|c|c|c|}
\hline Ano PPC & Carga Horária & Número de Vagas & Duração \\
\hline 2012 & 2952 & 40 vagas & 4 anos \\
\hline
\end{tabular}

Fonte: UFJ (PPCs dos cursos).

O egresso deve estar qualificado de forma competente e criativa como educador em Física para a Educação Básica. Deve, também, estar pronto para atuar de forma especializada na disseminação de conhecimentos da Física e suas tecnologias a partir de associações como instrumentos para uma pedagogia ativa.

Sendo assim, o conteúdo curricular é bastante extenso para a efetiva atuação desses profissionais em seus trabalhos e na vida social, sobretudo enquanto educadores. No curso de Física, independente da habilitação, como os educandos necessitam de amparo teórico na área específica, também precisam embasar o contexto da diversidade, mas nada consta 
referente ao assunto em sua matriz curricular.

\subsection{Curso de Licenciatura em Química}

O curso de Química foi integrado à expansão de interiorização para o efetivo Ensino Superior em Jataí. Até então, era promovido pelo MEC, pois era grande a falta de profissionais que ministravam a disciplina. A capacidade desse curso fez com que a integração desses educandos que cursam Licenciatura em Química contribuísse diretamente para a formação e aprendizado de educandos da Educação Básica. Outras informações estão dispostas no Quadro 7:

Quadro 7: Dados Gerais do PCC do Curso de Química.

\begin{tabular}{|c|c|c|c|}
\hline Ano PPC & Carga Horária & Número de Vagas & Duração \\
\hline 2015 & 3208 & 45 vagas & 7 anos \\
& & & \\
\hline
\end{tabular}

Fonte: UFJ (PPCs dos cursos).

O estudante desse curso contribuirá na atuação de conceitos teóricos sobre a matéria, que permitam o entendimento de suas manifestações e transformações nos aspectos quantitativo e qualitativo, compreendendo, assim, o conhecimento empírico suficiente para a percepção de seus fenômenos.

O curso de Química vem contemplando em seu PPC a formação ética e a função social do profissional. O ensino de química no Ensino Médio tem como finalidade principal a formação cidadã e é impossível pensar essa construção sem a valorização da diversidade e a discussão dessa temática nas disciplinas que auxiliarão o futuro professor a se entender como agente social e histórico no combate aos estigmas e preconceito.

\subsection{Curso de Licenciatura em Letras}

O curso de Letras disponibiliza, anualmente, por meio de processos seletivos, aulas nos períodos matutino e vespertino, sendo no período vespertino somente licenciatura em Português, ainda que haja a possibilidade de cursar outras disciplinas em outros turnos quando houver vagas. Sobre mais informações do curso, disponibilizamos no Quadro 08 abaixo:

Quadro 8: Dados Gerais do PCC do Curso de Letras.

\begin{tabular}{|c|c|c|c|}
\hline Ano PPC & Carga Horária & Número de Vagas & Duração \\
\hline 2007 & 3.048 & 160 vagas & 4 anos \\
\hline
\end{tabular}

Fonte: UFJ (PPCs dos cursos).

O egresso desse curso será um profissional crítico e reflexivo, com capacidade de estar preparado para exercer práticas cotidianas de qualidade reflexiva; ademais, que esteja preparado para exercer a formação continuada, considerada, assim, eixo epistemológico da linguagem e seus fenômenos (psicológicos, socioculturais e políticos).

O objetivo do curso é formar profissionais que sejam capazes de transcender as dificuldades necessárias e complexas, que transcendam a educação básica do ensino de jovens e adultos. O referente curso, por sua vez, não tem em suas disciplinas obrigatórias ou mesmo optativas de núcleo livres disciplinas que tratem a temática de gênero em seu currículo.

\subsection{Curso de Licenciatura em Educação Física}

O curso surgiu a partir de 2006, quando o então Campus Jataí adquiriu uma autonomia pedagógica. Em 2007, o PPC 
passou por alguns ajustes sem apresentação de mudanças relacionadas à estrutura curricular, pois esperavam a primeira turma em curso terminar para avaliarem a possibilidade de subsidiar a construção de um novo PPC. Outras informações estão dispostas no Quadro 9 abaixo:

Quadro 9: Dados Gerais do PCC do Curso de Educação Física.

\begin{tabular}{|c|c|c|c|}
\hline Ano PPC & Carga Horária & Número de Vagas & Duração \\
\hline 2017 & 3.216 & 40 vagas & 6 anos \\
\hline
\end{tabular}

Fonte: UFJ (PPCs dos cursos).

Espera-se que os estudantes tenham formação para desenvolver habilidade e teorias de cunho técnico e profissional que lhes são oportunizadas durante o curso e que sejam capazes de atuar criticamente acerca de sua profissão pedagógica e social.

Esses acadêmicos, futuros profissionais, terão atuação com educandos o qual partilharão de um caminho rico em diversidade nas redes públicas e particulares. Por se tratar de uma disciplina que requer desenvolturas para as práticas de exercícios físicos, em sua grande parte, torna-se um local rico de observações e falácias referentes ao comportamento que sai do padrão normativo. Em sua matriz curricular não se encontra nada de conteúdo para o aprimoramento desse profissional referente ao tema da diversidade.

\section{Considerações Finais}

Apesar das condições de normas impostas e conhecidas como únicas e naturais em suas extremidades, hoje, devem-se compreender em nossa sociedade os diversos jeitos de ser e as diferentes formas de relacionamento entre as pessoas. $\mathrm{Na}$ contemporaneidade, o sexo não é mais reconhecido como um processo de hierarquia para a reprodução humana, pois pode e deve ser reconhecido como forma de prazer, dependendo da escolha do indivíduo. Partimos da premissa de que vivemos em um país livre.

Deste modo, o que temos como ponto de partida em um sistema ativo no processo de estudos para compreensão da diversidade sexual e de gênero é a escola. A instituição torna-se um veículo de mão dupla que precisa ter amparo teórico e apoio de políticas educacionais para lidar com novos tempos. Portanto, se o professor estiver amparado de estudos que contribuam durante sua formação acadêmica sobre as temáticas de diversidade de gênero, saberão, portanto, optar com atitudes e condições que venham a dar apoio e defender vítimas de homofobia.

O professor, quando preparado, é capaz de desconstruir o olhar discriminatório referente à condição e ao caso que esteja sendo exposto em sala de aula. Ele deve, então, trabalhar de forma clara e simples o assunto, de modo que flua e seja explorado naturalmente. Uma vez esclarecidos, os estudantes irão desconstruir os conceitos que foram instituídos acerca daqueles que são colocados à margem, embora não tratemos de minorias, mas de uma grande parte da sociedade. Na linha de frente dos grupos LGBTTT, há ativistas que lutam e reconhecem os seus direitos e tentam mostrar que são cidadãos comuns como qualquer outro.

Ao analisarmos as matrizes curriculares, compreendemos o quanto é importante a condição do educador para contribuir com respeito à diversidade sexual e de gênero, facilitando o entendimento dos indivíduos desde a educação infantil até chegar ao ensino superior. Assim, se cada professor contribuir para o esclarecimento de dúvidas que venham a surgir, contribuirão para a formação de indivíduos pensantes para o exercício da cidadania.

Diante desse quadro, consideramos que a educação heteronormativa dê lugar aos estudos sobre educação sexual. 
Dessa maneira, vamos ao encontro das noções desenvolvidas por Furlani (2011), que contribui com diversas ideias e explicações de conteúdos que ajudam nesse debate sobre uma futura educação sexual em sala de aula.

Ao pensarmos em algumas propostas para o tema em sala de aula, Furlani (2011) elaborou oito princípios que irão assegurar essa educação como direito adquirido e seguro. Esses princípios precisam estar respaldados desde a educação infantil e se fazer presentes no currículo escolar. A autora aborda que existem opiniões de educadores que argumentam que essa educação sexual só seria necessária no ciclo do $5^{\circ}$ ao $9^{\circ}$ ano; no entanto, desde a educação infantil, as crianç as apresentam sua sexualidade e agem de acordo como se sentem, de maneira espontânea. Para citar um exemplo, eles trocam carícias quando vão juntos aos banheiros - em casos isolados, como o recreio ou outras situações.

Um caso comum é quando um menino ou uma menina pega no órgão genital do outro e, chegando em casa, relata o ocorrido de forma bem natural, o que faz com que muitas vezes seu responsável vá até a escola e converse com o educador. Esse profissional precisa ter amparo para falar sobre o assunto com os pais e com seus alunos, a fim de uma compreensão saudável acerca de suas sexualidades. É preciso explicar o que acontece com a curiosidade de seus corpos de forma simples, com o objetivo de que entendam tranquilamente, e não de forma opressiva e ideológica.

Por fim, ao chegando ao término deste artigo, fica evidente o quanto o auxílio é emergente para que os professores sejam preparados para a diversidade. Acreditamos de imediato que precisamos de novas práticas pedagógicas que modifiquem o olhar e o reconhecimento das diversidades desde a infância. Se agirmos de forma simples e segura, desestabilizaremos um sistema que há décadas contribui para inúmeros casos de vítimas de homofobia.

As análises das matrizes curriculares apontam que, nos cursos de licenciatura em Pedagogia, Matemática, Biologia, História, Geografia, Educação Física, Física, Letras e Química, infelizmente ainda não se aplicam de forma obrigatória ou como núcleos livres disciplinas que apresentem esses estudos. Verificamos, assim, que, apesar da evolução com o passar do tempo em vários aspectos e em instituições sociais, a educação ainda é retrógrada e existem barreiras que impedem o referente tema de ser explorado pelos educadores e educandos.

Poderíamos, então, pensar em uma educação sexual efetivamente programada e eficaz. Devem-se trazer as desconstruções de diversos fatores para uma educação sexual comprometida com a multiplicidade sexual e de gênero, que possa ser transformadora nos essencialismos e naturalismos que tantas vezes atuam de forma discriminatória e homofóbica.

Quando os educadores e os educandos tiveram a oportunidade de trabalharem com o ensino, gerando a desconstrução desse tempo em que necessitamos de muito estudo, libertaremos a sociedade de suas prisões individuais e ambos se tornarão formadores em instituir uma sociedade com justiça igualitária. Assim, faremos com que todos tenham conhecimento da realidade, tornando-a esclarecedora e tornando-nos cientes de que estamos em uma sociedade com múltiplas diferenças e arranjos.

Para que isso chegue a ser explorado, estudado e conceituado, necessitamos de profissionais que se envolvam e estejam abertos ao progresso evidente que a educação necessita ter. Com isso, teremos tranquilidade para prosseguir esse caminho de inter-relações diversas e domínios de complementos que gerarão mudanças para as relações entre indivíduos que atuarão com empatia, sabendo contribuir em uma socialização mais amena e com a diversidade em sua totalidade.

\section{Referências}

Aranha, A.V. Soares (2011). Diversidade e Formação Docente: Um desafio para o avanço da educação. Revista Brasileira de Pesquisa sobre Formação de Professores - Formação Docente, 04(03), 55.

Balieiro, F. de F., \& Risk, E. N. (2014). Escola e sexualidades: uma visão crítica à normalização - A heteronormatividade e suas implicações na educação. In: Júnior, J. L.; \& MIskolci, R. (Orgs.). Diferenças na educação: outros aprendizados. EdUFSCar.

Beleli, I. (2014). Gênero: Uma definição de gênero. In: Miskolci, Richard (Org.). Marcas da diferença no ensino escolar. EdUFSCar. 
Brasil. Constituição Federal, 1988.

Brasil. (2013). Ministério da Saúde. Secretaria de Gestão Estratégica e Participativa. Departamento de Apoio à Gestão Participativa. Mulheres Lésbicas e Bissexuais: direitos, saúde e participação social. Ministério da Saúde.

Dinis, F. N. (2011). Homofobia e educação: quando a omissão também é signo de violência1: Educar em Revista, Curitiba, Brasil, (39), 39-50.

Foucault, M. (2014). História da sexualidade 1 A vontade de saber: Tradução: Maria Thereza da Costa Albuquerque e J. A. Guilhon Alburquerque. Paz \& Terra.

Furlani, J. (2007). Sexo, Sexualidade e gêneros: monstruosidades no currículo da Educação Sexual: Educação em Revista, (46): $269-285$.

Furlani, J. (2011). Educação sexual na sala de aula: relações de gênero, orientação sexual e igualdade étnico-racial numa proposta de respeito às diferenças. Autêntica.

Grossi, M. P. (1998). Identidade de gênero e sexualidade: O que é gênero? Volume 24 de Antropologia em primeira mão. Universidade Federal de Santa Catarina, Programa de Pós-Graduação em Antropologia Social.

Junqueira, R. D. (Org.). (2009). Homofobia nas escolas: Um problema de todos. In: Junqueira, Rogério Diniz (Org.). Diversidade Sexual na Educação: Problematizações sobre a homofobia nas escolas. Brasília: Ministério da Educação, Secretaria de Educação Continuada, Alfabetização e Diversidade, UNESCO.

Louro, G. L. (1997). Gênero, sexualidade e educação: Uma perspectiva pós-estruturalista. (6a ed.), Vozes.

Louro, G. L. (2009). Heteronormatividade e Homofobia, In: Junqueira, Rogério Diniz (Org.). Diversidade Sexual na Educação: Problematizações sobre a homofobia nas escolas. Brasília: Ministério da Educação, Secretaria de Educação Continuada, Alfabetização e Diversidade, UNESCO.

Louro, G. L. (2010). O Corpo Educado: Pedagogias da Sexualidade. (3a ed.), Silva, T. T. da (Trad.). Autêntica.

Louro, G. L. (2014). Gênero, sexualidade e educação: Uma perspectiva pós-estruturalista. (16a ed.), Vozes.

Moreno, M. (1999). Como se ensina a ser menina: o sexismo na escola. Araújo, Ulisses Ferreira (Coord.); Fuzatto, Ana Venite (Trad.). São Paulo: Moderna; Campinas/SP: Editora da Universidade Estadual de Campinas.

Pamplona, R. S. (2012). O Kit anti-homofobia e os discursos sobre diversidade sexual. Dissertação (Mestrado) - Universidade Federal de São Carlos (UFSCar).

Pelúcio, L. (2014). Desfazendo o gênero: Gênero ou gêneros? In: Júnior, Jorge Leite; Miskolci, Richard (Orgs.). Diferenças na educação: outros aprendizados.

Peres, W. S. (2009). Cenas de exclusões anunciadas: travestis, transexuais, transgêneros e a escola brasileira. In: Junqueira, Rogério Diniz (Org.). Diversidade Sexual na Educação: Problematizações sobre a homofobia nas escolas. Brasília: Ministério da Educação, Secretaria de Educação Continuada, Alfabetização e Diversidade, UNESCO.

Rios, R. R. (2009). Homofobia na perspectiva dos direitos humanos e no contexto dos estudos sobre preconceito e discriminação: Anti-semitismo, racismo e sexismo diante da homofobia, In: Junqueira, Rogério Diniz (Org.). Diversidade Sexual na Educação: Problematizações sobre a homofobia nas escolas. Brasília: Ministério da Educação, Secretaria de Educação Continuada, Alfabetização e Diversidade, UNESCO.

Silva, T. T. da. (1999). Documentos de Identidade: uma introdução às teorias do currículo. (2a ed.), Autêntica. 